\title{
Shark Finning Legislation and Shark Welfare. An Analysis of the Kristin Jacobs Ocean Conservation Act
}

\author{
Rosa María Cajiga \\ MA Animal Law and Society (UAB)
}

Received: March 2021

Accepted: October 2021

Recommended citation. CAJIGA, RM., Shark finning legislation and shark welfare. An analysis of the Kristin Jacobs Ocean Conservation Act, dA. Derecho Animal (Forum of Animal Law Studies) 12/3 (2021). DOI https://doi.org/10.5565/rev/da.566

\begin{abstract}
Thousands of sharks are cruelly killed worldwide every day due to the lucrative shark finning trade. This practice is negatively impacting marine life, as sharks are the greatest ocean predators and maintain the delicate balance of the marine ecosystem. Shark finning consists of removing the fins and discarding the rest. The sharks are alive during the process, and when tossed back into the water without fins they cannot swim, thus sinking to the depths where they asphyxiate and / or are devoured by other fish. The fins are primarily consumed in China, Hong Kong, Taiwan, and Asian communities elsewhere in the world for making shark-fin soup. Efforts to stop the practice of shark finning vary, ranging from demanding fisheries to bring sharks to land before removing the fins, to prohibiting the trade of shark products, to the total ban of shark fishing. Legislation varies significantly between countries and states, ranging from zero to absolute protection, whereby absolute means prohibiting the possession, sale, importation and exportation of shark fins. The economic implications of the shark-fin trade are considerable, which renders the application of laws and regulations very difficult. However, the increasing business of diving with sharks offers an alternative that shows us that the value of a living shark is far greater than when it is sold for parts. Analyzing legislation from the United States, as well as international legislation, aims to show its weakness when it comes to efforts to protect sharks, and in particular the application of the concept of shark welfare when legislating in their favor. The case study will focus on the Kristin Jacobs Ocean Conservation Act, investigating and analyzing the legal efforts made in the state of Florida (USA) to stop shark finning, and analyzing the legal implications for shark welfare.
\end{abstract}

Keywords: sharks; oceans; product; trade; legislation.

Resumen - El bienestar de los tiburones y la legislación sobre el aleteo. Un análisis del Kristin Jacobs Ocean Conservation Act

Miles de tiburones son cruelmente asesinados todos los días alrededor del mundo gracias al lucrativo comercio de las aletas de tiburón. Esta práctica está impactando negativamente la vida marina ya que los tiburones son los mayores depredadores del océano, los que mantienen el delicado balance de los ecosistemas marinos. El aleteo de tiburón consiste en desprender las aletas y desechar el resto del animal. Los tiburones están vivos durante este proceso y cuando son lanzados de vuelta al agua sin sus aletas ya no pueden nadar, así que se hunden hasta el fondo donde se asfixian y/o son devorados por otros peces. Las aletas son usadas mayormente 
en China, Hong Kong, Taiwan y comunidades asiáticas en otras partes del mundo para la elaboración de la sopa de aleta de tiburón. Los esfuerzos para detener la práctica del aleteo de tiburón varían, desde exigir a las pesquerías que lleven los tiburones a tierra antes de cortar las aletas hasta la prohibición total de la pesca de tiburón, pasando por la prohibición del comercio de productos de tiburón. La legislación varía muchísimo entre países y estados, teniendo desde un nivel cero de protección a una protección total, por total refiriéndome a la prohibición del aleteo del tiburón, así como su posesión, venta, importación y exportación. Las implicaciones económicas del comercio de aletas de tiburón son considerables, lo que hace la aplicación de leyes y regulaciones muy difícil, pero el creciente negocio del buceo con tiburones ofrece una alternativa que nos revela que el valor de un tiburón vivo es mucho mayor a cuando se vende por partes. Analizando la legislación de los Estados Unidos, así como la internacional, se pretende mostrar las debilidades de éstas al intentar proteger al tiburón, en particular la aplicación del concepto de bienestar de los tiburones al momento de legislar en favor de ellos. El caso de estudio será el Kristin Jacobs Ocean Conservation Act, donde se investigarán y analizarán los esfuerzos legales hechos en el estado de Florida (EEUU) para detener el aleteo de tiburón y se analizarán las implicaciones legales en el bienestar de los tiburones.

Palabras clave: tiburones; océanos; producto; comercio; legislación.

\section{Contents}

Introduction

1. Shark finning, a cruel practice

2. Understanding Sharks

3. The Exclusion of Sharks from Animal Welfare Legislation

4. Shark Finning Legislation in the US

5. Case Study, Kristin Jacobs Ocean Conservation Act

6. Importance of Stronger legislation for Sharks

Conclusion

$\begin{array}{ll}\text { Abbreviations } & \\ \text { AWA } & \text { Animal Welfare Act } \\ \text { CITES } & \text { Convention on International Trade in Endangered Species of Wild Fauna and Flora } \\ \text { CFR } & \text { Code of Federal Regulations } \\ \text { CMS } & \text { Convention of Migratory Species of Wild animals } \\ \text { COFI } & \text { Committee of Fisheries } \\ \text { ESA } & \text { Endangered Species Act } \\ \text { FAO } & \text { Food and Agriculture Organization of the United Nations } \\ \text { FDA } & \text { Food and Drug Administration } \\ \text { FWC } & \text { Florida Fish and Wildlife Conservation Commission } \\ \text { FWS } & \text { Fish and Wildlife Service } \\ \text { HMSA } & \text { Humane Slaughter Act } \\ \text { IPOA-Sharks } & \text { International Plan of Action for Conservation and Management of Sharks } \\ \text { IUCN } & \text { International Union for the Conservation of Nature } \\ \text { KJOCA } & \text { Kristin Jacobs Ocean Conservation Act } \\ \text { MoU } & \text { Moratorium of Understanding } \\ \text { NGO } & \text { Non-Governmental Organization } \\ \text { NMFS } & \text { National Marine Fisheries Service } \\ \text { NOAA } & \text { National Oceanic and Atmospheric Administration } \\ \text { NPOA-Sharks } & \text { National Plan of Action for the Conservation and Management of Sharks } \\ \text { OIE } & \text { World Organization for Animal Health } \\ \text { SCA } & \text { Shark conservation Act } \\ \text { USDA } & \text { United States Department of Agriculture } \\ \text { WOAH } & \text { World Organization of Animal Health. } \\ & \end{array}$




\section{Introduction}

For over 400 million years, sharks have been swimming the oceans as the trophic apex predator of the marine ecosystem, maintaining its health. These majestic, well-adapted fishes are cunning, intelligent, highly social, which, according to experts, might feel pain. Despite the existence of scientific evidence of all this, sharks are greatly misunderstood. For centuries sharks have been hunted for their meat and other products, especially their fins, used to elaborate shark fin soup and traditional medicine applications in Asian countries. Since shark meat has not been considered an economic value, sharks are usually finned by fishermen. Once in the boat, the well-priced fins are removed from the shark's body while still alive, and then the rest of the animal is tossed back into the water. As most sharks need to swim to breathe and without fins, they cannot swim, they die of affixation or are eaten alive by other predators. Fishers practice this cruel and barbaric method to save fuel and storage space on their boats since they only carry the valuable fins: this is shark finning.

For some years now, the US government has become aware of this cruel practice and has created Laws and Regulations to stop it, at least within its borders. In addition, international organizations have created legal instruments to preserve sharks and stop the rapid decline of their populations, such as the Convention on International Trade in Endangered Species of Wild Fauna and Flora (CITES), which has included some shark species in their Appendixes I and II. Unfortunately, despite all these attempts, the lack of enforcement and legal loopholes permit shark finning to continue, and shark deaths are increasing year by year. This situation leads us to think that we might need to tackle this problem from another perspective and find other solutions to protect these animals.

In this work, the weaknesses of the current legal attempts to protect sharks and explore a concept of welfare for sharks will be examined. In fact, not all animals are legally protected at the same level; legislation makes a difference among species. Speciesism among our animal legislation seems to be a prevalent accepted issue, which needs to be addressed. To do so, the current shark legislation at an international level and in the US will be reviewed to determine if it is doing enough to protect sharks from the cruel practice of shark finning and consequently from its possible extinction, not only from a conservation point of view but from an animal welfare perspective. Analyzing the most recent legislation on shark-finning, the Kristin Jacob Ocean Conservation Act (Florida, US), it will be determined to what extent this legislation protects sharks. Furthermore, some recommendations for broader regulations and more efficient enforcement will be provided.

\section{Shark Finning, a Cruel Practice}

\subsection{What Does Shark Finning Mean?}

Shark finning represents one of the most harmful practices in the fishing industry, not only for sharks but for the marine ecosystem and consequently for human survival. Sharks are apex predators in many marine ecosystems; therefore, their disappearance can cause dangerous health imbalances in the ocean, putting at risk the productivity of oceans and the dependent livelihoods and economies. Sharks are particularly vulnerable to extinction due to their biological reproductive characteristics. Too little is known about sharks' environmental and health necessities; therefore, too little is yet understood about their welfare. Due to a lack of interest in acquiring scientific knowledge about these animals, they are often left out of the legal and regulatory frameworks that could deliver some protection.

Typically, sharks are finned alive brought aboard fishing vessels to have their fins sliced off, and then thrown back into the sea, where they suffocate, bleed to death, or are eaten by other animals. Appallingly, the animals are usually conscious through much of the ordeal. ${ }^{1}$

The Law explains what is finning to determine when a shark has been legally caught.

Finned means one or more fins, including the caudal fin (tail), are no longer naturally attached to the body of the shark. A shark with fins naturally attached, either wholly or partially, is not considered finned. ${ }^{2}$

\footnotetext{
${ }^{1}$ Animal Welfare Institute, Shark Finning, website: https://awionline.org/content/shark-finning [Last visited May 18, 2021]

${ }^{2}$ Florida Administrative Code R. 68B-44.002 (2020), Definitions,

website: www.flrules.org/gateway/RuleNo.asp?ID=68B-44.002 [Last visited May 18, 2021]
} 
Sharks usually possess six types of fins, each one of them is valued differently in the market according to their qualities. "The most valuable are the first dorsal, pectorals and lower caudal. The other fins, smaller anal, pelvic, second dorsal and upper caudal are also traded, but are less valuable" ${ }^{3}$. Fins must be processed to become dry; drying methods vary from or salting to mechanically drying fins, which large-scale fin processors usually carry out. Thus, shark fin products can be acquired at different processing stages, including wet fins, raw fins, semi-prepared, fully prepared, and frozen-prepared, among others.

Up to 100 million sharks are killed annually, and the most are used to elaborate shark fin soup. Stephanie Brendel, the director of Shark Allies, declares that: "Of all the threats finning is the most significant." This problem has brought the attention of many people, given the brutality of this practice. As a result, the public is progressively showing more and more concern about the health of the environment and animal welfare.

\subsection{The Finning Business}

According to the Food and Agriculture Organization (FAO), shark meat has been consumed and traded since the IV century BC. The commercial exploitation of sharks started after the First World War.

Shark meat was considered a poor person's food and sharks were mainly caught, in the fifties, for their vitamin A-rich liver oil. However, the waste of up to 75-80 percent of raw material led businesses and countries to improve fishing/processing technologies and marketing/distribution strategies, in order to generate a wider acceptance of shark meat. ${ }^{4}$

Due to the high commercial value of shark fins and, ironically, the relatively low value of shark meat, fishers often take only the fins of these animals and leave the rest of the body behind. These animals can be hefty, which translates into higher fuel consumption for fishing boats, therefore more expenses, and less profit.

The practice of shark finning exponentially increased since the late 90's principally due to the growing demand for their fins used for shark fin soup and also traditional cures, particularly in the Chinese market, as a result this brought the improvement of fishing technology therefore increased the market ${ }^{5}$

Shark finning is a widely illegal business that plants the seed for other types of illegal businesses and corruption.

Shark finning is the driving cause of shark extinction. High demand for fins is the underlying incentive for humans to kill sharks for their fins, mainly because the market is so lucrative. Fins are considered the most valued part of a shark and consumers are willing to pay considerable money for them. Because shark finning is so lucrative, regulations are often overlooked. ${ }^{6}$

Shark finning is a worldwide common practice, especially in areas with no legislation, poor local enforcement, and corruption. For example, the famous non-governmental organization (NGO) Sea Shepherd revealed during its work in Costa Rica:

We have watched as the shark population in the waters around Cocos Island and along the coast of Costa Rica have declined at an alarming rate. It is a serious situation and this diminishment is being fuelled by Costa Rican political and bureaucratic corruption. ${ }^{7}$

It is relevant to mention that the practice of shark finning serves to other illicit businesses, such as the illegal traffic of drugs in the border region with Florida and countries of Latin America. The significant decline

\footnotetext{
3 MARSHALL, L. - BARONE, M., Shark Fin Guide: identifying sharks from their fins (Rome 2016) 8, website: www.fao.org/3/i5445e/i5445e.pdf

${ }^{4}$ VANNUCCINI, S., Shark Utilization, Marketing and Trade (Rome 1999)

website: www.fao.org/3/x3690e/x3690e00.htm\#Contents [Last visited May 18, 2021]

${ }_{6}^{5} \mathrm{Id}$.

${ }^{6}$ TRAN B., Eating Our Way to Their Extinction: What Florida Should Learn From California on Banning Shark Fin Soup and the Shark Fin Trade (Seattle 2019)

website: https://digitalcommons.law.seattleu.edu/cgi/viewcontent.cgi?article=1079\&context=sjel [Last visited May 18, 2021]

7 Sea Shepherd UK, Sharks, Drugs, Lies, and Corruption in Costa Rica, website: www.seashepherd.org.uk/news-andcommentary/commentary/sharks-drugs-lies-and-corruption-in-costa-rica.html [Last visited May 18, 2021]
} 
in population and poor reporting from the governments have raised concerns about legislating sharks better.

Shark finning has affected the conservation status of shark species worldwide, leading several countries, including the US, EU, Canada, Australia, Argentina, Mexico, South Africa, Brazil, Costa Rica, and Taiwan, to adopt shark finning bans in their national waters as a strategy to prohibit shark finning. ${ }^{8}$

Finning is not only a cruel practice; it is also an unsustainable and inefficient business, given that most of the shark's body is not commercialized, just discarded to the ocean, wasting with this a valuable source of protein and revenue.

\subsection{Cultural \& Religious Implications}

There is a controversy surrounding the famous Chinese cuisine dish, Shark fin soup. Many protesters are lobbying for a ban on the harvesting of shark fins, but the consumers of this dish argue that these bans are used to target Chinese and Asian populations: "Shark fin has been a delicacy in Chinese cuisine since the Sung dynasty (AD 960-1279) and during the Ming dynasty (AD 1368-1644) shark fin soup was a traditional dish for the emperor." 9

Preparing this soup also involved the risk of catching sharks, which served as a tribute to the emperor; shark fins were not very easy to find, so this gave the soup an element of rareness, making it unique. "The consumption of strong or fierce animals, such as sharks, was believed to give strength, and thus was considered suitable for the imperial family" 10 The connection between shark fins and beliefs about health and vitality played a significant role in shark exploitation.

In today's Chinese society, the role of shark fin soup is considered just symbolic and a way to show status. Given that one bowl of soup can cost up to 100usd, it can be considered the culinary equivalent of wearing a designer bag. In reality, shark fins are of no culinary relevance for the soup since they do not have any actual flavor; they are composed of cartilage and merely add a particular texture to the soup. The broth is made from chicken or pork and other ingredients to add flavor, and the shark fins provide the soup with little more than a cool name.

Shark fins themselves are tasteless and offer little nutritional value. They contain high levels of methyl mercury and other dangerous toxins that can be fatal in large quantities. Over time, even at relatively small doses they can cause significant health problems for consumers including damage to the brain, heart, kidneys, lungs, and immune system. ${ }^{11}$

Given the fact that shark products, in general, have shown to be of no value to human health, conservation groups, legislator, and rule-makers have a strong starting point to create a legitimate strategy to end not only the finning business but also to offer more integral protection for sharks from other harmful consumption practices. Arguments involving human health are often more convincing than those focused on conservation, welfare, or even the environment.

\section{For the Maori people, Sharks are part of the cultural heritage}

Hawaiian mythology often features sharks, including stories of men who could toggle between shark and human form or have shark jaws on their backs. It also refers to many shark gods or deified ancestor guardians, such as shark "aumakua," one of the most popular among fishing people who becomes their pet, driving fish into the family net, warding danger, and receiving food. Although ruling chiefs primarily forbade sorcery, shark "aumakua" could be used to help kill enemies. The most revered of the shark gods is "Kamohoali'i" who can assume both human and fish forms. He had many temples dedicated to him on the island of Molokai, but a summit cliff on the crater of Kilauea is one of his most sacred spots. Finally, "Dakuwaqa" was a shark god in Fijian mythology who was the eater of lost souls.

In Māori culture, the sea is often considered to be the foundation and source of all life. Islands are seen

\footnotetext{
${ }^{8}$ DELL'APA, A. - CHAD SMITH, M. - KANESHIRO-PINEIRO, M.Y., The Influence of Culture on the International Management of Shark Finning, in Environmental Management (2014),

website: https://doi.org/10.1007/s00267-014-0291-1 [Last visited May 18, 2021]

${ }^{9}$ Id.

${ }^{10} \mathrm{Id}$.

${ }^{11}$ Animal Welfare Institute, Shark Finning, website: https://awionline.org/content/shark-finning [Last visited May 18, 2021]
} 
as fish drawn up from the water, and people are considered to have evolved from amphibious beginnings. "Traditional Māori knowledge includes genealogies of fish and other marine creatures, and numerous stories and legends are dramas of underwater life." 12

"Kaitiakitanga" should be defined not only as "guardianship" as has been emphasized by the Crown, local government and some Maori, but also as "resource management". "Kaitiakitanga" embraces social and environmental dimensions. Human, material and non-material elements are all to be kept in balance. ${ }^{13}$

This concept is not only defined in the hearts and culture of the Maori people is also part of their New Zeeland Law in section 2 of the Resource Management Act 1991 as:

The exercise of guardianship by the "tangata whenua" of an area in accordance with "tikanga" Maori in relation to natural and physical resources, and includes the ethic of stewardship," and in section 2 of the Fisheries Act 1992 as: The exercise of guardianship; and, in relation to any fisheries resources, includes the ethic of stewardship based on the nature or the resources, as exercised by the appropriate "tangata whenua" in accordance with "tikanga" Maori. ${ }^{14}$

\section{Understanding Sharks}

When we hear the word shark, a vision of a sleek ravening sea monster comes to our mind because sharks are a popular character in many fiction novels. Unfortunately, a concept such as this does no justice to sharks. These animals are very different from one another, and they show a diversity of form, habitat, diet, and development equal to that of many other, better-known animal groups. Within the limitations of their marine environment, they invade many niches and exhibit a variation in structure, enabling them to pursue many more ways of life than the fiction writer would have us believe. Most sharks live far more social lives and appear likely to have distinct personalities. Some species of solitary sharks meet for breeding or at rich hunting grounds, which may lead them to cover thousands of miles in a year.

Shark migration patterns may be even more complex than in birds, with many sharks covering entire ocean basins. Sharks can be highly social, remaining in large schools. Sometimes more than 100 scalloped hammerheads congregate around seamounts and islands, e.g., in the Gulf of California. ${ }^{15}$

\subsection{Sharks, Their Importance to Our Oceans}

By protecting the animals, we help to protect the environment where they inhabit. "By taking sharks out of the coral reef ecosystem, the larger predatory fish, such as groupers, increase in abundance and feed on the herbivores. With less herbivore, macroalgae expand, and coral can no longer compete, shifting the ecosystem to one of algae dominance, affecting the survival of the reef system." ${ }^{16}$ In addition, as predators, they shift their prey's spatial habitat, which alters the feeding strategy and diets of other species. Therefore, all shark species are essential; one example of a shark that represents a vital role in the function of the sea is the Tiger Shark.

The Story of the Tiger Shark and the Sea Grass: These sharks love to hunt in shallow bay waters, which is where you'll find sea grass. Sea grass is important for the earth's climate because it pulls carbon dioxide from the atmosphere. Turtles and sea cows know that Tiger Sharks frequent the sea grass, so they often avoid these areas to avoid becoming shark lunch. Due to this, the sea grass becomes long and lush, providing shelter for small fish and shellfish that people like to catch. If sharks were taken away from the planet, the turtles and sea cows would eat the sea grass, depleting it down to nothing.

\footnotetext{
12 TE AHUKARAMŪ, C.R., Tangaroa - the sea - The importance of the sea, Te Ara - the Encyclopedia of New Zealand, website: www.TeAra.govt.nz/en/tangaroa-the-sea/page-1 [Last visited May 20, 2021)

13 KAWHARU, M., Kaitiakitanga: a Maori anthropological perspective of the Maori socio-environmental ethic of resource management, The Journal of the Polynesian Society (2000), vol. 109, no. 4, pp. 349-370, website: www.jstor.org/stable/20706951 [Last visited May 19, 2021].

${ }^{14}$ Resource Management Act 1991, Section 2, New Zeeland, website: www.legislation.govt.nz/act/public/1991/0069/latest/DLM230272.html [Last visited May 19, 2021]

${ }^{15}$ COMPAGNO, L. - DANDO, M. FOWLER, S., Sharks of the World (London 2005)

${ }^{16}$ Oceana, The Importance of Sharks, website: https://europe.oceana.org/en/importance-sharks-0 [Last visited May 20, 2021]
} 
Result: less atmospheric protection for the world and less small fish and shellfish for the fisherman. ${ }^{17}$

Through spatial control and abundance, sharks indirectly maintain the sea grass and corals reef habitats. Therefore, the loss of sharks will lead to a dramatic decline in coral reefs, sea grass beds, and finally, the loss of commercial fisheries.

Sharks play a crucial role in many marine ecosystems. Sharks are top predators; they maintain a crucial balance in the food chain. In addition, they help remove the sick animals and keep a balance with competitors helping to ensure species diversity. For example, in the Gulf of Mexico:

At least 16 species of coastal sharks from four families (Carcharhinidae, Sphyrnidae, Ginglymostomidae, Triakidae) utilize Gulf of Mexico waters off Florida and Texas as primary and nursery areas. From 1991 to 2004, data were collected on 12,879 neonate, and older juveniles of these 16 species in the US Gulf of Mexico, primarily in coastal waters of the Florida peninsula and secondarily along the Texas coast. ${ }^{18}$

"The importance of Florida and Texas coastal habitats in the early life history of Gulf of Mexico sharks underscores the need for conservation of these areas to help rebuild depleted shark populations." ${ }^{19}$ There is an urgent need to protect these areas and create sufficient scientific funding to carry out these much-needed studies to determine the areas of total protection if needed. "Available data show a high anthropogenic pressure on sharks. However, due to the poor level of human knowledge of sharks, it is very difficult to calculate its true extent." ${ }^{20}$ It is crucial to have correct and reliable data about shark populations and their biological aspects before making decisions and implementing ineffective bans or restrictions that could do more harm than good, and we should remember that what cannot be measured cannot be controlled.

Sharks have low reproductive rates, making repopulation difficult. Balance in nature is very delicate; removing one member of an ecosystem could cause its destruction. Not only are coral reefs stunning, but they are also vital to the ocean's balance. The chain of adverse effects caused by the extinction of sharks could be devastating: other large predatory fish will reproduce and thrive and will hunt small herbivore fish in significant quantities; the decline of herbivore populations will allow algae to grow to a point which coral will die leading to the extinction of the whole ecosystem. When algae thrive and grow without control make the water slimy and dense, which can cause the death of many species over time as sunlight could not penetrate beneath the surface.

Shark conservation also will lead to healthier ecosystems, therefore to a better economy, health, and security for the communities and the state. Fisheries will also be directly affected by the absence of sharks: the decrease in Great White populations near North Carolina, for example, led to a larger population of rays which consumed a hole population of bay scallops in that region, causing a local fishery to close. The gastronomic industry has also felt the drop in shark populations when other predators who feed on marine species such as clams and scallops multiply. Restaurants in certain areas cannot offer the very popular clam chowder anymore since quahogs are not available in the local markets. The income of these restaurants has been seriously affected.

\subsection{Key Facts About Sharks for the Law}

Sharks have been swimming the world's oceans for millions of years before humans. The prehistoric nature of sharks is just one characteristic that makes them fascinating creatures in the sea. According to the 68B-44.002 definitions: "Shark means any species of the orders Carcharhiniformes, Lamniformes, Hexanchiformes, Orectolobiformes, Pristiophoriformes, Squaliformes, Squatiniformes"21

Sharks are defined as fishes, but different from what we could consider a typical fish, like salmon or goldfish, which are bony fish and belong to the Osteichthyes Class.

\footnotetext{
${ }^{17}$ ROGERS, M., Why All Shark Species Are Important, website: www.sharksider.com/shark-species-important/ [Last visited May 20, 2021]

${ }^{18}$ HUETER, R. - TYMINSKI, J., Species-Specific Distribution and Habitat Characteristics of Shark Nurseries in Gulf of Mexico

Waters off Peninsular Florida and Texas Center for Shark Research (USA 2007)193

${ }^{19}$ Idem.

20 CATARCI, C., World Markets and Industry of Selected Commercially-Exploited Aquatic Species with an International Conservation Profile (Rome 2004), website: www.fao.org/3/y5261e/y5261e08.htm [Last visited May 20, 2021]

${ }^{21}$ Florida Administrative Code R. 68B-44.002 (2020), Definitions,

website: www.flrules.org/gateway/RuleNo.asp?ID=68B-44.002
} 
Sharks belong to the class Chondrichthyes (chondrichthyans), which differ from Osteichthyes or bony fish as their skeleton is cartilaginous. The class Chondrichthyes or chondrichthyans is divided into two subclasses: Holocephalii (chimeras, elephant fish) and Elasmobranchii (Elasmobranchs: sharks and batoids such as skates, rays, torpedoes, 20 and sawfish). ${ }^{22}$

There is great diversity among sharks, their size from the smallest to the largest members. In terms of overall length, the largest species known, the Whale Shark, is at least thirty times longer than the smallest and certainly reaches more than $18 \mathrm{~m}$. In contrast, the smallest species, the cat sharks and smooth dogfishes, mature at lengths of $30 \mathrm{~cm}$ and never grow much beyond that.

The Checklist of Living Elasmobranchs (Compagno 1999) reports 465 shark species, grouped into 35 families. Elasmobranchs are into two super orders (Galea and Squalea), ten orders, 44 families, 108 genera, and some 480 species. $^{23}$

Sharks have a fascinating variety of adaptations that make them impeccably suited to their environment. Shape, color, and sizes vary considerably between shark species due to their evolution in separate environments. It is not surprising that they have gained a status for being some of the most impressive and formidable predators on the planet.

Shark skeletons are made of cartilage and connective tissue, contrary to bony fish and other terrestrial vertebrate animals. This variation is merely adaptive; cartilage is lighter than bone, reducing the skeleton's weight, therefore helping them save energy. Their lack of bones and ribcage is a disadvantage outside water, because their weight on land can easily crush them. We can only imagine what happens to a shark's body when captured and thrown carelessly onto a boat or ship. Another disadvantage is that sharks can only swim forward; this is because, unlike bony fish, their pectoral fins cannot bend upwards.

Sharks also present prolonged rates in their physical development and sexual reproduction; therefore, it is vital to legally declare more marine protected areas for nurseries. Besides creating more marine protected areas, there is also the need to control these areas efficiently. With the participation of local communities and governments, outstanding achievements can be made.

Some species reach their sexual maturity within one year; others may reach it within twenty or twentyfive years. Some species are very short-lived; others may reach up to 60 years. They inhabit a wide range of habitats. The majority of sharks are pelagic species; others reside in freshwater lakes and rivers. A half of all species are found up to a depth of 200 meters; another third inhabits deeper waters to 2 000 meters. Only 5 percent of shark species are truly oceanic. ${ }^{24}$

Most sharks have six fins; each fin represents a different value on the market. Caudal fins are the most expensive ones; the bigger the fin, the higher the price; this significantly affects bigger shark species, such as the basket nose shark, whale shark, and great white shark.

Shark fins predominantly consist of soft collagen and elastin fibers called ceratotrichia, commonly referred to as fin rays or fin needles, which are used to prepare shark fin soup and other shark fin products. There are typically six types of fin on a shark, the first and second dorsal, caudal, anal, pelvic (paired), and pectoral (paired) fins. ${ }^{25}$

It is essential to know certain aspects of shark's physiology to understand the brutality of the practice of shark finning. Sharks are different from other fishes; they will drown if they stop swimming because most sharks need to swim continuously to stay alive. "Sharks obtain oxygen for breathing from the water that flows over their gills. If they stop swimming, no more water flow means no more oxygen, so breathing stops." ${ }^{26} \mathrm{We}$ would never consider doing this to a pig or a cow, less to a dog or a cat. Any action like this would be considered a cruelty crime against animals in many state codes in the United States.

\footnotetext{
22 CATARCI, C., World Markets and Industry of Selected Commercially-Exploited Aquatic Species with an International Conservation Profile (Rome 2004), website: www.fao.org/3/y5261e/y5261e08.htm

${ }^{23} \mathrm{Id}$.

${ }^{24}$ Id.

${ }^{25}$ MARSHALL, L. - BARONE, M., Shark Fin Guide: identifying sharks from their fins (Rome 2016) 8, website: http://www.fao.org/3/i5445e/i5445e.pdf [Last visited May 20, 2021]

${ }^{26}$ Id.
} 


\subsection{The Concept of Shark Welfare}

The concept of shark welfare is turned out to be strange and absent among the current legislators, government, and even scientists; this is probably due to the concept of animal welfare itself, given that it is commonly used for domestic animals and the animals in our care such as farmed animals and pets. The majority of wild animals are often left out of welfare considerations due to the lack of research on the welfare of wild animals in general, particularly sharks. There are no distinct guidelines for welfare for sharks, which can lead to animal cruelty. Scientists have researched the capacity of bony fish to feel pain; however, the research on Elasmobranchii is significantly smaller and still inconclusive. Nevertheless, according to Dr. Lynne Sneddon "caution should be applied to ruling out nociception in sharks, skates and rays given the very meager number of published studies." 27 There is a strong need to extend research on this group of aquatic animals to develop a concept of shark welfare.

For other terrestrial animals, we know that:

The concept of animal welfare includes three elements: the animal's normal biological functioning (which, among other things, means ensuring that the animal is healthy and well-nourished), its emotional state (including the absence of negative emotions, such as pain and chronic fear), and its ability to express certain normal behaviors (Fraser et al., 1997). ${ }^{28}$

The World Organisation for Animal Health considers that animal welfare is when animals are "healthy, comfortable, well-nourished, safe, and are also free from pain, fear, distress. Also, when they can express behaviors that are important for its physical and mental state". ${ }^{29}$

The "Five Freedoms" principle offers an advantageous and practical approach to the study of welfare and, especially, its assessment on livestock farms and during the transport and slaughter of farm animals. It has additionally served as the basis for many animal protection Laws in the European Union and other parts of the world. However, despite its straightforward utility, it has not been used in wild animals, especially in sharks. When we consider animal welfare, we should keep in mind that animal suffering is, without a doubt, a crucial issue in the argument on animal welfare. Consequently, situations that could potentially cause suffering, such as shark finning, are welfare problems.

Animal welfare is becoming a foremost priority for many people worldwide who increasingly want better welfare practices to be included in treating animals used for food and other forms of production. Consequently, citizens and lawmakers need to have a dialogue about animal welfare regarding wild animals, particularly sharks. The inhumane slaughtering of sharks in the finning industry is a welfare issue. Sharks deserve the same dignity, respect, and humane treatment as any other animal. The fact that sharks are not under our care does not mean that we cannot offer them protection against potential pain and suffering.

We should consider an ethical and more scientific approach when treating these animals., this does not necessarily mean that we should avoid using such animals but that we should do so as humanely as possible to improve their welfare when they are under our care, even for a few minutes in their last moments.

\section{Sharks as Abnormal Creatures}

The fishing industry denies the claims that fish can feel pain. According to the Mexican Society of Cartilaginous Fish (Sociedad Mexicana de Peces Cartilaginosos, SOMEPEC): "sharks are classified as abnormal creatures with no ability to feel." It is not surprising that the most prominent fishing industry funds SOMEPEC in Mexico. The denial of considering sharks as sentient might be profitable for the industry to continue exploiting these animals.

When talking about pain in sharks, we have to clarify the difference between expressing and feeling pain. As humans, we can understand and read a human response to pain or discomfort, but in the case of other animals appears to be sometimes more challenging to understand. Specifically, there appears to be a communication problem between humans and sharks, given that we live in different environments, this limits the contact, therefore creating distance. The body language of Sharks is very different from any mammal body language, with no facial expressions that we can understand and no perceivable sounds to the human ear. They

\footnotetext{
${ }^{27}$ SNEDDON, L., Pain in aquatic animals. The Journal of experimental biology(2015), 218(7), p.969.

${ }^{28}$ MANTECA, X. - MAINAU, E. - TEMPLE, D., What is animal welfare?, website: www.fawec.org/en/fact-sheets/28-generalwelfare/106-what-is-animal-welfare [Last visited May 20, 2021]

${ }^{29}$ World Organization of Animal Health (OIE), Introduction to the recommendations for animal welfare, website: https://www.oie.int/fileadmin/Home/eng/Health_standards/tahc/2018/en_chapitre_aw_introduction.htm [Last visited May 20, 2021]

86 Derecho Animal. Forum of Animal Law Studies, vol. 12/3
} 
also have senses that we do not have. All of this makes it very difficult for humans to create a connection; therefore, feel empathy or compassion for sharks as we could feel for other animals that are more often in contact with us.

Interpreting pain gets more challenging with non-mammals such as reptiles, fish, insects, etcetera, which "cannot make facial expressions like mammals many do not even have eyelids," words from Bree Putman, a postdoctoral fellow at the Natural History Museum of Los Angeles. However, that does not mean they do not hurt: "Reptiles, amphibians, and fish have the neuroanatomy necessary to perceive pain," according to the book Pain Management in Veterinary Practice. ${ }^{30}$

Many shark species have brains as complex as those of mammals, enabling them to process a wide range of senses. Sharks have the same five senses as we do but can also sense electrical currents and pressure changes; they might even be more sensitive than we are.

The mediation of nociception with analgesic medications has not been well documented in elasmobranchs. However, they possess many of the same nociceptive anatomic and biochemical structures as mammals, including similar spinothalamic pathways, opioid receptors, endogenous opioids, and cyclooxygenase (COX) enzyme, suggesting that pain perception in these animals is likely similar to that in mammals. ${ }^{31}$

Despite all these studies, there is still a lack of funding and support for researchers in this field. However, if there is doubt whether or not these animals can feel pain, the Law should protect them. In this case, the precautionary principle should be applied.

\section{The Exclusion of Sharks from Animal Welfare Legislation}

\subsection{International Laws and Regulations}

Some countries worldwide have implemented laws, regulations, and guidelines to consider the welfare of some aquatic animals. Many of these Laws are used to protect sharks and maintain a viable fishery stock, disregarding individual welfare. There is a vast global market of sea products; this market is expanding every year. Many shark species are pelagic; they migrate, not only across national waters but also through international waters, which makes it very hard to regulate fisheries without cooperation among nations. Since none of the international protection measures available are legally binding, we also encounter a lack of enforceability. Some crucial concerns for sharks in the international legislation comprise the areas of international trade of sharks and their products, sharks as a food source, the realm of experimentation, wildlife conservation, and last but not least, climate change.

\section{IPOA-Sharks}

The International plan of action for the conservation and management of sharks (IPOA-Sharks) was produced in 1999 by the UN Food and Agriculture Organization (FAO). This first multilateral organization tackled shark finning recommending that sharks should not be fished only for their fins. The UN General Assembly and some regional fisheries management organizations have repeatedly recommended that sharks be fully utilized, but these recommendations are not legally binding. In March 1997, during the $22^{\text {nd }}$ session of the FAO Committee of Fisheries (COFI), FAO observed reports on the expanding catches and the potential negative impact on shark populations and decided to launch an expert consultation to develop guidelines to create a Plan of Action to improve conservation and management of sharks which would be submitted at the next session of the COFI.

\footnotetext{
30 LANGLEY, L., The Surprisingly Humanlike Ways Animals Feel Pain, website: www.nationalgeographic.com/animals/article/animals-science-medical-pain [Last visited May 20, 2021]

${ }^{31}$ DAVIS, M. - DUNN, J. - RAYMOND, F. - MYLNICZENKO, N. - STORMS, T., Pain Control in Elasmobranchs? Evaluation of Butorphanol and Ketoprofen as Analgesics in Chain Dogfish (Scyliorhinus retifer), (Dallas 2005), website: www.vin.com/apputil/content/defaultadv1.aspx?pId=11257\&catId=32333\&id=3865178\&ind=276\&objTypeID=17 [Last visited May 20, 2021]
} 
The International Plan of Action for Conservation and Management of Sharks (IPOA-SHARKS) was developed through the meeting of a Technical Working Group on the Conservation and Management of Sharks in Tokyo from 23 to 27 April 1998 and the Consultation on Management of Fishing Capacity, Shark Fisheries and Incidental Catch of Seabirds in Longline Fisheries held in Rome from 26 to 30 October 1998 and its preparatory meeting held in Rome from 22 to 24 July $1998 .{ }^{32}$

The IPOA-Sharks works with fisheries on management practices through voluntary actions with no rewards or sanctions to ensure sustainability and creates comprehensive national plans that include record keeping, data analysis, and increased research.

\section{The Convention on International Trade in Endangered Species of Wild Fauna and Flora}

The Convention on International Trade in Endangered Species of Wild Fauna and Flora (CITES) is an international agreement; its goal is to ensure the international trade of specimens of wild animals and plants to not become a threat to the survival of the species populations in order to ensure this control three Appendices determine the restrictions on the import, export, re-export, and introduction from the sea. Trade restrictions and regulations depend on whether a species is listed under Appendix I, Appendix II, or Appendix III. Aquaculture issues arise under CITES when parties harvest and trade commercially exploited aquatic species listed in the CITES Appendices. They elaborate and expedite permits and certificates to apply the regulation internationally to ensure that such trade is legal, sustainable, and traceable. The endangered species of wild animals and plants listed are taken into consideration at the moment of trading.

Sharks had first included in CITES appendices in 2003. As of 2015, eight species of sharks and all manta rays are included in Appendix II (species not necessarily threatened with extinction, but whose international trade must be controlled in order to avoid utilization incompatible with their survival); and all species of sawfishes are in Appendix I (species threatened with extinction, whose international trade is permitted only in exceptional circumstances) (CITES, 2015). ${ }^{33}$

\section{Animal Welfare in CITES}

CITES covers some elements related to the facilities used to house animals and some provisions about their transport; these could be considered a welfare strategy, but they are scarce and insufficient. Besides these regulations, there is no concept of Animal Welfare in CITES.

Following the Convention on International Trade in Endangered Species of Wild Fauna and Flora (CITES) does not mention the potential damage that trade might cause to each individual of the species or populations concerning animal welfare. ${ }^{34}$

According to animal transportation, CITES establishes in different points that the trade-in specimens require an authority to verify that all live specimens are conditioned and transported in a way that minimizes the risk of injuries, deterioration in their health, or mistreatment. This provision appears in articles III, IV, and $\mathrm{V}$ that regulate trade in specimens of species included in Appendix I, II, and III, respectively, and that affect exports, re-exports, and introductions from the sea, although in the latter case, the statement is something different but with the same essence and purpose.

Besides preventing trade from jeopardizing or being inconsistent with the conservation of biological diversity, this work analyses to which extent CITES takes into account the protection of animals individually considered as sentient beings and if it would be necessary to propose new instruments that might improve outcomes concerning this issue, either by adding new requirements and/or reinforcing the existing ones. ${ }^{35}$

\footnotetext{
32 Food and Agriculture Organization, International Plan of Action for Conservation and Management of Sharks, website: www.fao.org/ipoa-sharks/en/ [Last visited May 24, 2021]

${ }^{33}$ MARSHALL, L. - BARONE, M., Shark Fin Guide: identifying sharks from their fins (Rome 2016) 7 , website: http://www.fao.org/3/i5445e/i5445e.pdf [Last visited May 24, 2021]

${ }^{34}$ ARRIBAS, M., Protection of Animals in the Convention on International Trade in Endangered Species of Wild Fauna and Flora (CITES) (Andalucía 2016) 6, website: https://dspace.unia.es/handle/10334/3493 [Last visited May 24, 2021]

${ }^{35}$ Idem.
} 


\section{International Union for the Conservation of Nature (IUCN)}

IUCN is a membership Union composed of both government and civil society organizations. It harnesses the experience, resources, and reach of its more than 1,400 Member organizations and the input of more than 18,000 experts. This diversity and vast expertise make IUCN the global authority on the status of the natural world and the measures needed to safeguard it. ${ }^{36}$

The assessment work of the IUCN keeps the world informed about the status of threatened species, alerting authorities to take measures to protect those species. For example, according to the IUCN list of threatened species, $36 \%$ of sharks and rays species are threatened with extinction. The IUCN even counts with a shark specialist group:

The IUCN Shark Specialist Group (SSG) has long been a trusted source of science-based information and advice on sharks and their relatives. This solid reputation has been built on widespread interest in the IUCN Red List as a means of identifying and prioritizing species at risk, monitoring threats, and evaluating conservation action. Our work continues to center on finding expert consensus as to the global status of species and is guided by the following principles:

- Sharks, rays, and chimeras have ecological, economic, and cultural value;

- Policies regarding these species should be founded on sound science;

- Fishing and other forms of exploitation should be managed for sustainability;

- Minimizing waste is essential, particularly given declining food security;

- Communicating the outcomes of SSG initiatives to policy-makers, non-governmental organizations, and the public can lead to improvements in the population status of sharks, rays, and chimeras. ${ }^{37}$

\section{Convention of Migratory Species of Wild animals (CMS)}

The Convention of Migratory Species of Wild animals provides tools that help improve shark protection at the international level by listing species specified in appendices. Appendices I and II of the Convention contain several species of sharks and rays at risk of becoming endangered, similarly protecting migratory species as CITES. Migratory species which are endangered and therefore considered at risk of extinction are listed in Appendix I. "CMS Parties strive towards strictly protecting these animals, conserving or restoring the habitats in which they live, mitigating obstacles to migration, and controlling other factors that might endanger them." 38

To ensure that directed and non-directed shark fisheries are sustainable, CMS established a Moratorium of Understanding (MoU) on the Conservation of Migratory Sharks. Although not legally binding, this MoU exhorts participants to implement shark conservation plans seeking to raise understanding of migratory shark populations and urge the conservation of critical habitats and migratory corridors and nurseries, extremely important in the early life stages of sharks. CMS also tries to raise public awareness of the threats sharks and their habitat face and promote national, regional, and international collaborations and encourage public participation in conservation activities.

\section{World Organization for Animal Health (OIE)}

This international organization has the mission to provide a better guarantee for food safety of animal origin and promote animal welfare through a science-based approach, among other things. While the OIE's primary focus is on animal health and diseases to safeguard humans, it is also involved in developing work related to animal welfare. The OIE Aquatic Animal Health Code (the Aquatic Code) provides standards for improving aquatic animal health worldwide. The Aquatic Code provides sanitary measures for the import and export of aquatic animals to prevent the spread of disease via international trade in the aquatic animals and their products. However, this only includes standards for farmed fish welfare; this excludes wild fish, namely sharks.

\footnotetext{
${ }^{36}$ International Union for the Conservation of Nature, About, website: www.iucn.org/about [Last visited May 24, 2021]

${ }^{37}$ IUCN Shark Specialist Group, What We Do, website: www.iucnssg.org/what-we-do.html [Last visited May 24, 2021]

${ }^{38}$ Convention of Migratory Species, Introduction, website: www.cms.int/en/page/introduction-0 [Last visited May 24, 2021]
} 


\subsection{US Legislation on Animal Welfare}

The lack of scientific information about sharks and their capabilities results in the commonly accepted dogma that these animals cannot feel pain, think, or even suffer. Sharks are less studied than farmed terrestrial animals; consequently, this is reflected in our legal system where sharks are primarily ignored or explicitly excluded from the laws conferring some legal protections to animals.

In the existent Legislation about conservation, the main goal is to preserve specific species lucrative for the trade. In the case of sharks, the United States of America guidelines are based on how to fish them, type of species, the quantity of catch of that specific species, and fishing season. Many marine "conservation" Laws used to protect sharks are based on maintaining a viable fishery stock; this is not ideal but at least serves as an excellent argument to protect some animal individuals.

The Law and the Fishing Industry often disregard sharks individuals, sharks and other fishes are counted in tons of fish when fished; they are not even considered individuals like farmed animals usually are., this shows us the lack of regard that exists for these animals.

In the United States, there is no specific regulation to ensure the humane treatment of sharks. There is little to no information about how sharks should be treated and slaughtered; this matter needs to be discussed.

What else is it that should trace the insuperable line? Is it the faculty of reason, or perhaps, the faculty for discourse?...the question is not, Can they reason? Nor, Can they talk? But, Can they suffer? Why should the law refuse its protection to any sensitive being?... The time will come when humanity will extend its mantle over everything which breaths ${ }^{39}$

\section{The Animal Welfare Act (AWA)}

In 1966, the Congress of the United States of America adopted the Animal Welfare Act (AWA) "to ensure that animals intended for use in research facilities, for exhibition purposes, or use as pets are provided humane care and treatment." 7 USC $\S 2131(1)$. In 2002, Congress amended the AWA to require that the US Department of Agriculture (USDA) adopt standards to protect the birds that are not "bred for use in research." 7. USC $\S 2143$ (a) (1), 2132 (g). Following this amendment, the USDA should have adopted specific regulations regarding birds but has not yet done so. Currently, fish are not included under the AWA.

Animal means any live or dead dog, cat, nonhuman primate, guinea pig, hamster, rabbit, or any other warm-blooded animal, which is being used or intended for research, teaching, testing, experimentation, or exhibition purposes, or as a pet. This term excludes birds, rats of the genus Rattus, and mice of the genus Mus, bred for use in research; horses not used for research purposes; and other farm animals, such as but not limited to, livestock or poultry used or intended for use as food or fiber, or livestock or poultry used or intended for use for improving animal nutrition, breeding, management, or production efficiency, or for improving the quality of food or fiber. The term means all dogs, including those used for hunting, security, or breeding purposes. ${ }^{40}$

Most animals used by humans have an exclusion in the AWA's protection, not only birds but also rats or mice used in research, livestock used for food or fiber, reptiles, amphibians, fish, etc. invertebrates; therefore, this Act excludes sharks. This exclusion is relevant since all these animals represent a significant number and create incoherencies between what is considered an animal. The AWA in this context is also contradictory; in some of the statutes, it benefits certain animals, but for others does not offer any protection or any consideration, including sharks; this Act has a minimal scope on protecting the welfare of all animals.

\section{The Lacey Act}

This Act was initially created to preserve game and wild birds by making it a federal crime to poach game in one state to sell the bounty in another. Another primary concern was the potential problem of introducing non-native or exotic species of birds and animals into native ecosystems. The Lacey Act, 16 USC $\S \S 3371-3378$ protects both plants and wildlife by creating civil and criminal penalties for a wide array of violations. The Act prohibits trade in wildlife, fish, and plants that have been illegally taken, possessed, transported, or sold.

\footnotetext{
${ }^{39}$ BENTHAM, J., Introduction to the Principles of Morals and Legislation (London 1823), 122

${ }^{40}$ Animal Welfare Regulations of 1966, 9 Code of Federal Regulations $§ 1.1$ - Definitions, 31

website: www.aphis.usda.gov/animal_welfare/downloads/bluebook-ac-awa.pdf [Last visited May 21, 2021]

90 Derecho Animal. Forum of Animal Law Studies, vol. 12/3
} 
The Lacey Act has been amended several times since its inception in 1900. The most significant ones occurred in 1969, 1981, and 1988. The 1969 amendments expanded to include amphibians, reptiles, mollusks, and crustaceans. The maximum penalty was increased to $\$ 10,000$ with possible imprisonment for one year. Additionally, the mental state required for a criminal violation was increased to "knowingly and willfully;" civil penalties were expanded to apply to negligent violations ${ }^{41}$.

In 1981, Congress removed the heightened proof standard of "willfully" from the statute, making "knowingly" the standard., this came in response to increased illegal trade in fish and wildlife both domestically and abroad.

The amendments also allowed for warrantless arrest for felony violations under the Act and expansion of the role of federal wildlife agents.

The felony provision was amended, making any witness that knows about the import or export of the species or where he or she was involved in the sale or purchase of wildlife, fish, or plants with a market value greater than $\$ 350$ could be convicted ${ }^{42}$.

This Act is positioned as one of the most comprehensive forces at the federal level to combat wildlife crime. It is now an important weapon to protect animals domestically and abroad; this is significant due to increasing international and domestic wildlife trafficking activity.

\section{The Humane Slaughter Act}

The Humane Slaughter Act (HMSA) does not contemplate the humane slaughter of sharks. HMSA covers livestock animals, such as cattle, calves, horses, mules, sheep, swine, and "other livestock," which has been interpreted to include goats and "other equines." (HMSA § 1902(a); CFR § 313.15, § 313.16) Poultry and other animals used for human consumption have also been excluded from HMSA's protection.

\section{US Food \& Drug Administration, Sea Food \& Meat Food}

The Food and Drug Administration (FDA) is responsible, among other things, for the safeguarding of the nation's seafood supply, both domestic and imported, also that this food is safe, sanitary, wholesome, and honestly labeled. In this regulation, the humane slaughter of sea animals, namely sharks, is not addressed or even mentioned.

Fish and Fishery Products

(d) Fish means fresh or saltwater finfish, crustaceans, other forms of aquatic animal life (including, but not limited to, alligator, frog, aquatic turtle, jellyfish, sea cucumber, and sea urchin, and the roe of such animals) other than birds or mammals, and all mollusks, where such animal life is intended for human consumption.

(i) Preventive measure means physical, chemical, or other factors that can be used to control an identified food safety hazard. ${ }^{43}$

Current good manufacturing practice

(a) Except as provided by $\S 117.5$ (b), parts 110 and 117 of this chapter apply in determining whether the facilities, methods, practices, and controls used to process fish and fishery products are safe and whether these products have been processed under sanitary conditions.

(b) The purpose of this part is to set forth requirements specific to the processing of fish and fishery products. ${ }^{44}$

\footnotetext{
${ }^{41}$ WISCH, R., Michigan State University College of Law (2003),

website: www.animallaw.info/article/overview-lacey-act-16-usc-ss-3371-3378 [Last visited May 21, 2021]

${ }^{42}$ Idem.

${ }^{43}$ Food and Drug Administration, Fish and Fishery Products of 2020, 21 CFR, $\S 123.3$ Definitions,

website: www.accessdata.fda.gov/scripts/cdrh/cfdocs/cfcfr/CFRSearch.cfm?fr=123.3 [Last visited May 21, 2021]

${ }^{44}$ Food and Drug Administration, Fish and Fishery Products of 2020, 21 CFR, § 123.5 Current good manufacturing practice,

website: www.accessdata.fda.gov/scripts/cdrh/cfdocs/cfcfr/CFRSearch.cfm?fr=123.3 [Last visited May 21, 2021]
} 
Human treatment of sea animals is not even considered a good manufacturing practice. Humane slaughter of fish, sharks or any other aquatic animal is not yet a big concern.

\section{Federal Meat Inspection Act}

In this Act, the concerns regarding humane slaughter are present, but just for livestock animals, I wonder why humane slaughter is different from the previous regulation about fish and fishery products which the main concern is just about product safety? Are sea animals just perceived as seafood products and not animals who can feel pain?

(j) The term "meat food product" means any product capable of use as human food which is made wholly or in part from any meat or other portion of the carcass of any cattle, sheep, swine, or goats, excepting products which contain meat or other portions of such carcasses only in a relatively small proportion or historically have not been considered by consumers as products of the meat food industry, and which are exempted from the definition as a meat food product by the Secretary under such conditions as he may prescribe to assure that the meat or other portions of such carcasses contained in such product are not adulterated and that such products are not represented as meat food products. This term as applied to food products of equines shall have a meaning comparable to that provided in this paragraph concerning cattle, sheep, swine, and goats." 45

\section{Subchapter I - Inspection Requirements; Adulteration \& Misbranding}

$\S 603$ Inspection of meat and meat food products

(a) Examination of animals before slaughtering; diseased animals slaughtered separately and carcasses examined

(b) Humane methods of slaughter

For the purpose of preventing the inhumane slaughtering of livestock, the Secretary shall cause to be made, by inspectors appointed for that purpose, an examination and inspection of the method by which amenable species are slaughtered and handled in connection with slaughter in the slaughtering establishments inspected under this chapter. The Secretary may refuse to provide inspection to a new slaughtering establishment or may cause inspection to be temporarily suspended at a slaughtering establishment if the Secretary finds that any cattle, sheep, swine, goats, horses, mules, or other equines have been slaughtered or handled in connection with slaughter at such establishment by any method not in accordance with the Act of August 27, 1958 (72 Stat. 862; 7 USC 1901-1906) until the establishment furnishes assurances satisfactory to the Secretary that all slaughtering and handling in connection with slaughter of livestock shall be in accordance with such a method. ${ }^{46}$

There is no evidence in any legislation of any method to prevent the humane slaughter of sharks; the fishing methods for sharks that exist are commonly based on the safety of fishers and profit. Since the fishing industry has been growing at such a level and knowing that aquatic animals are often counted in tons, not as individuals, there is an urgent need to voice these animals in the legal realm from such cruel devastating practices. Like any other animal, Sharks deserve to be treated with the same level of dignity and respect, including the time of death.

\section{The Endangered Species Act (ESA)}

The Endangered Species Act (ESA) of 1973 was created to: "provide a means whereby the ecosystems upon which endangered species and threatened species depend may be con-served" ${ }^{47}$ In words of the president at the time, Richard Nixon, on December 28, 1973, while signing the act: "Nothing is more priceless and more worthy of preservation than the rich array of animal life with which our country has been blessed."

\footnotetext{
${ }^{45}$ Federal Meat Inspection Act of 1906, 21 United States Code Annotated (USCA), §601 Definitions, website: www.govinfo.gov/content/pkg/USCODE-2014-title21/html/USCODE-2014-title21-chap12-subchapI-sec601.htm [Last visited May 21, 2021]

46 Federal Meat Inspection Act of 1906, 21 USCA, §603 Inspection of meat and meat food products, website: www.govinfo.gov/content/pkg/USCODE-2014-title21/html/USCODE-2014-title21-chap12-subchapI-sec603.htm [Last visited May 21, 2021]

${ }^{47}$ Endangered Species Act of 1973, 16 U.S.C., Conservation, $\$ 1531$ (b), website:

https://uscode.house.gov/view.xhtml?path=/prelim@title16/chapter35\&edition=prelim[Last visited May 21, 2021]

92 Derecho Animal. Forum of Animal Law Studies, vol. 12/3
} 
The Endangered Species Act is a crucial instrument to take advantage of the current legal system and protect sharks in the wild and even in captivity. The ESA is administered by the US Fish and Wildlife Service (FWS) and the National Marine Fisheries Service (NMFS). Domestic and foreign species of animals (both vertebrate and invertebrate), as well as plants, can be listed, either as endangered, which means a species is in danger of extinction throughout all or a significant portion of its range or also as threatened, which means a species is likely to become endangered within the foreseeable future, according to an assessment of the risk of their extinction and including subspecies, varieties and, for vertebrates, distinct population segments are eligible for listing, except pest insects.

Once a species is listed, the Act provides tools to aid the species' conservation and recovery and protect its habitat. Most of the large terrestrial predators, bears, lions, wolves, and tigers are protected, but only two distinct population segments of the scalloped hammerhead shark are listed as endangered, and two are listed as threatened under the Endangered Species Act.

Their status is: ESA Endangered Eastern Pacific, ESA Endangered Foreign, Eastern Atlantic, ESA Threatened Central \& Southwest Atlantic, ESA Threatened Indo-West Pacific, and CITES Appendix II Throughout Its Range. ${ }^{48}$

Given that some of the most valuable and commercialized products are made out of these animals are often targeted for over exploitation. Terrestrial animals are targeted, but also the ones that live in the sea, such as sharks.

The NMFS has conferred ESA protection on a shark species by adding four "distinct population segments" of scalloped hammerhead sharks to the list of species protected under the ESA. NMFS determined that scalloped hammerhead sharks in the Eastern Atlantic and Eastern Pacific are endangered, the ESA's most protected category and that scalloped hammerhead sharks in the Indo-West Pacific and Central and Southwest Atlantic are threatened.

Several efforts have been made to protect sharks in US territorial waters. The Shark Finning Prohibition Act of 2000 prohibited the importation of shark fins without the corresponding carcasses and the finning of sharks in US waters. The 2010 law took a step further, prohibiting US vessels in international waters, and all vessels in US waters, from transporting shark fins without the corresponding carcass or from removing any shark fin while at sea. Although shark finning is prohibited in the United States, the trade of shark fins is legal. United States is both an importer and exporter of shark fins, "In 2011, the US exported 38 tons of shark fins and imported 58 tons. Many countries that the US imports shark fins from do not have a ban in place, such as China, Indonesia, and Japan" ${ }^{\text {"T9 }}$.The weaknesses in both regulations have still brought many sharks deaths. "Fins from as many as 73 million sharks end up in the global shark fin trade every year. Furthermore, though the act of shark finning is illegal in US waters, shark fins continue to be bought and sold in many parts of the United States". ${ }^{50}$ The US also remains to import fins, also from countries with no finning bans in place.

\section{The Marine Mammal Protection Act}

The Marine Mammal Protection Act (MMPA) was enacted on October 21, 1972. All marine mammals are protected under the MMPA. The MMPA prohibits, with certain exceptions, the catching of marine mammals in US waters and by US citizens on the high seas and the importation of marine mammals and marine mammal products into the US.

The FWS and the NMFS share the Jurisdiction for MMPA. The Service's Branch of Permits is responsible for issuing take permits when exceptions are made to MMPA. In general, exceptions may be made for Pre-MMPA specimens taken before December 21, 1972; International Agreements entered into by the United States before December 21, 1972, Alaska natives, scientific research, public display, enhancing the survival or recovery of a species, incidental take in commercial fisheries, as well as waivers granted by the US Government. Since this Act is for the Marine Mammal Protection, their name clearly expresses that sharks are out of his protection.

\footnotetext{
${ }^{48}$ National Oceanic and Atmospheric Administration, Species directory, Scallop Hammerhead shark, website: www.fisheries.noaa.gov/species/scalloped-hammerhead-shark [Last visited May 21, 2021]

49 The Florida Senate, Bill CS/CS/CS/SB 680, Bill Analysis and fiscal impact statement (2020), website: https://www.flsenate.gov/Session/Bill/2020/680/Analyses/2020s00680.rc.PDF [Last visited May 31, 2021]

50 SHARPLESS A., The Value of Keeping Sharks Alive, Oceana (2017)[Blog], website: https://oceana.org/blog/value-keepingsharks-alive [Last visited May 31, 2021]
} 
(6) The term "marine mammal" means any mammal which (A) is morphologically adapted to the marine environment (including sea otters and members of the orders Sirenia, Pinnipedia, and Cetacea), or (B) primarily inhabits the marine environment (such as the polar bear); and, for this chapter, includes any part of any such marine mammal, including its raw, dressed, or dyed fur or skin.

(7) The term "marine mammal product" means any item of merchandise which consists, or is composed in whole or in part, of any marine mammal. ${ }^{51}$

The question remains why the distinction among aquatic animals was made; legislation should not be speciesist among animals.

(4) The term "humane" in the context of taking a marine mammal means that method of taking involves the least possible degree of pain and suffering practicable to the mammal involved. ${ }^{52}$

The consideration regarding humane as a humane practice of taking a marine animal shows to be not present in any of the current shark legislation quoted in this work. It has been researched that fishes can feel pain as much and in the same form as mammals. Sharks are socially intelligent animals that might feel pain and need the same protection as any other animal regarding their potential ability to feel and suffer.

\section{Shark Finning Legislation in the US}

\section{Shark Finning Prohibition Act of 2000}

This Act made it unlawful to possess a shark fin in US waters, and any fishing vessel within the United States waters, and all US flagged fishing vessels in international waters without the corresponding carcass. However, the ban did not require that carcasses be brought ashore with fins attached, relying instead on a finto-carcass ratio creating a loophole in the regulation. Many irregularities were observed when vessels were used to transport sharks' fins to land them in US ports, but the sharks were not fished or finned by those same vessels, making it very difficult to trace which fins belonged to which carcass.

\section{NPOA-Sharks 2001}

In 2001 USA developed the US National Plan of Action for the Conservation and Management of Sharks (NPOA-Sharks) through the NMFS to accomplish the requests of the IPOA-Sharks adopted by the FAO in 1999. The country is committed to ensuring that shark populations are maintained at sustainable levels. It is a priority for the NPOA-Sharks to outline the plans to meet the objectives of the IPOA-Sharks, including how the United States manages sharks, a group of species known to be vulnerable to overfishing. This is a great necessity because of the management challenges presented by sharks and other elasmobranchs. The unique characteristics of many elasmobranchs, such as late age of maturity, relatively slow growth rates, and low fecundity, result in low productivity in most species and make them more susceptible to overfishing. The recovery of populations from severe depletions may take many years for most elasmobranch species.

In addition, Elasmobranch fisheries assessments are further complicated because of the mobility of many species across political boundaries, even across oceans; a general lack of baseline information about the practices employed in shark fisheries worldwide; incomplete data on catch, effort, landings, and trade; and a lack of information on biological parameters, the importance of specific habitats to productivity, and population dynamics of many species. ${ }^{53}$ Consequently, shark finning is unsustainable; only do humans decimate shark populations, but sharks have low reproductive rates, making repopulation difficult. "Thus, fishing elasmobranchs down to unsustainable levels may occur rapidly, and successful management of elasmobranch fisheries requires a stronger commitment to fishery monitoring, biological research, and proactive management than many teleost fisheries." ${ }^{54}$ The NPOA-Sharks pursues the means for the US to pass these obstacles and promote the conservation and effective management of sharks.

\footnotetext{
${ }^{51}$ Marine Mammal Protection Act of 1972, 16 USC 1361-1407, § 1362, website: www.fws.gov/international/pdf/legislation-marinemammal-protection-act.pdf [Last visited June 10, 2021]

${ }^{52}$ Idem.

${ }^{53}$ Department of Commerce - NOAA - NMFS, US National Plan of Action for the Conservation and Management of Sharks (2001)

5, website: www.fao.org/3/br377e/br377e.pdf [Last visited May 31, 2021]

${ }^{54}$ Idem.

94 Derecho Animal. Forum of Animal Law Studies, vol. 12/3
} 


\section{Magnuson-Stevens Fishery Conservation and Management Act}

The Magnuson-Stevens Fishery Conservation and Management Act is the primary law governing marine fisheries management in the US at a federal level. One of the main objectives of this Act is to preserve animal species used for fishing, their habitats, and combat overfishing. The act urges to follow a more conservationist way of fishing, given the notable decline in fish stocks.

(2) Certain stocks of fish have declined to the point where their survival is threatened, and other stocks of fish have been so substantially reduced in number that they could become similarly threatened as a consequence of (A) increased fishing pressure, (B) the inadequacy of fishery resource conservation and management practices and controls, or $(\mathrm{C})$ direct and indirect habitat losses which have resulted in a diminished capacity to support existing fishing levels. ${ }^{55}$

A national program for the Conservation and Management of fishery resources is provided to prevent the decline of the marine ecosystem, therefore, the fishing resources.

(6) A national program for the conservation and management of the fishery resources of the United States is necessary to prevent overfishing, to rebuild overfished stocks, to ensure the conservation, to facilitate long-term protection of essential fish habitats, and to realize the full potential of the Nation's fishery resources. ${ }^{56}$

This Act also regulates foreign fishing and international fishery agreements, including permits for foreign fishing and import prohibitions. An essential part of the Act is the regulation of Moratoriums, namely the High Seas Driftnet Fishing Moratorium Protection Act; this includes prohibitions, negotiations, and certifications regarding the management and conservations of the living marine resources or the use of the high seas.

\section{Shark Conservation Act 2010 (SCA)}

This act amends the Magnuson-Stevens Fishery Conservation and Management Act and makes unlawful:

(i) to remove any of the fins of a shark (including the tail) at sea; "(ii) to have custody, control, or possession of any such fin aboard a fishing vessel unless it is naturally attached to the corresponding carcass; "(iii) to transfer any such fin from one vessel to another vessel at sea, or to receive any such fin in such transfer, without the fin naturally attached to the corresponding carcass; or "(iv) to land any such fin that is not naturally attached to the corresponding carcass or land, any shark carcass without such fins naturally attached;", 57

It also directs the NMFS to initiate a western Pacific long line fisheries cooperative research program.

\section{Shark Fin Sales Elimination Act 2019}

The Act makes it illegal to possess, buy, or sell shark fins or any product containing shark fins, except for particular dogfish fins. A person may possess a shark fin that was lawfully taken consistent with a license or permit under certain circumstances. This Act also addresses the inclusion of rays and skates in the Seafood Traceability Program. (The Seafood Traceability Program has data reporting and recordkeeping requirements at the time of entry for imported fish or fish products entered US commerce.) The Department of Commerce must revise its regulations to include rays and skates as species subject to the Seafood Traceability Program.

(a) Prohibition. Except as provided in sections 3 and 4, no person shall possess, offer for sale, sell, or purchase any shark fin or product containing any shark fin. ${ }^{58}$

\footnotetext{
55 Magnuson-Stevens Fishery Conservation and Management Act (1976), 16 USC, §1801, sec.2(a) Findings, website: www.govinfo.gov/content/pkg/COMPS-1678/pdf/COMPS-1678.pdf [Last visited May 31, 2021]

${ }^{56}$ Idem.

${ }^{57}$ Shark and Fishery Conservation Act (2009), Pub. L. No. 111-348, §103, 124 STAT. 3670,

website: www.congress.gov/111/plaws/publ348/PLAW-111publ348.pdf [Last visited May 31, 2021]

${ }^{58}$ Shark Fin Sales Elimination Act of 2019, H.R.737, §2
} 
Penalties are imposed for violations under the Magnuson-Stevens Fishery Conservation and Management Act.

(b) Penalty. For purposes of section 308(a) of the Magnuson-Stevens Fishery Conservation and Management Act (16 USC 1858(a), a violation of this section shall be treated as an act prohibited by section 307 of that Act. ${ }^{59}$

An exception was considered to balance the cost-benefit impact of this prohibition over the economy of the traditional fishing business. Since many people maintain from traditional fishing. Education and science were also contemplated in this exception.

Section 2 shall not apply concerning possession of a shark fin that was taken lawfully under a State, territorial, or Federal license or permit to take or land sharks if the shark fin is separated from the shark in a manner consistent with the license or permit and is:

(1) Destroyed or discarded upon separation;

(2) Used for non-commercial subsistence purposes under State or territorial law;

(3) Used solely for display or research purposes by a museum, college, or university, or by any other person under a State or Federal permit to conduct non-commercial scientific research; or

(4) Retained by the license or permit holder for a non-commercial purpose. ${ }^{60}$

Lastly, this act also excludes dogfish (smaller shark species) from protection.

(a) In General: It shall not be a violation of section 2 for any person to possess, offer for sale, sell, or purchase any fresh or frozen raw fin or tail from any stock of the species Mustelus canis (smooth dogfish) or Squalus acanthias (spiny dogfish). ${ }^{61}$

"Millions of pounds of spiny and smooth dogfish sharks are caught by fishermen every year, and only recently have managers begun to implement science-based quotas and consider the importance of reducing by catch, or the incidental taken of species." ${ }^{62}$ It is essential to point out that the actual number of this species population is unknown; consequently, we cannot be sure how much damage this exception is against dog fish populations and the marine ecosystem. "Even though smooth dogfish have never been formally assessed to determine how big the population is, fishermen are allowed to catch an unlimited, unregulated amount." 63

\subsection{Finning Bans at State Level}

Some states in the US have passed laws to ban the trade of shark fins. Hawaii, California, Oregon, Washington, Illinois, Maryland, Delaware, Nevada, New York, Massachusetts, Rhode Island, and the Northern Mariana Islands, American Samoa, and Guam have already banned the sale or trade of most shark fins in 2020 also Florida. However, the problem begins when these products are banned in one State; the market shifts to a new location.

In 2013, for instance, no shark fins were exported out of Savannah, Georgia. Nevertheless, after Texas began cracking down on the trade, the market shifted, and Savannah became the number one US city for shark fin exports. ${ }^{64}$

\section{Leading US Jurisdictions on Finning Bans: Texas \& California}

The lone star state was the first gulf state to enact the law to combat the shark fin trade. In 2016 Governor Abbott signed into law HB 1579, prohibiting the sale, trade, purchase, and transportation of shark

\footnotetext{
${ }^{59}$ Idem.

${ }^{60}$ Shark Fin Sales Elimination Act of 2019, H.R.737, §3

${ }^{61}$ Shark Fin Sales Elimination Act of 2019, H.R.737, §4

website: www.congress.gov/116/bills/hr737/BILLS-116hr737rfs.pdf [Last visited May 31, 2021]

62 KELEDJIAN, A., Spiny Dogfish Catch a Break-No More Shark Finning in the U.S.!, Oceana [Blog], website: https://oceana.org/blog/2014/11/spiny-dogfish-catch-a-break-no-more-shark-finning-in-the-us [Last visited May 31, 2021]

${ }^{63}$ Idem.

${ }^{64}$ SHARPLESS A., The Value of Keeping Sharks Alive, Oceana (2017)[Blog],

website: https://oceana.org/blog/value-keeping-sharks-alive [Last visited May 31, 2021]

96 Derecho Animal. Forum of Animal Law Studies, vol. 12/3
} 
fin. The Texas law, passed with bipartisan support in the Republican-dominated legislature, makes it a criminal act to buy or sell shark fins and even transport them commercially. Those convicted can face six months to one year in jail. Something particularly mentionable about Texas is that state and federal law enforcement agencies are working together to combat shark finning at ports of entry and the interior of the state: the Texas Game Wardens, US Fish and Wildlife Service (FWS), US Customs and Border Protection. Texas Game Wardens are inspecting wholesale commercial fish dealers, retailers, restaurants, and commercial vessels.

Texas is also applying a broad strategic approach consisting of law enforcement intervention. State/local law enforcement, federal law enforcement, and community outreach by sharing education, information with the Texan community on the issue and working with their commercial fishing partners to report any illegal activity; this might be the best way to take down the finning business for good.

The California legislature passed a bill prohibiting the possession, sale, trade, or distribution of shark fins, coming into effect as a law on January 1st, 2012. Restaurants were given a phase-out period of one year until January 1st, 2013. California has about 1/3 of the country's Asian population and used to be one of the largest consumers of shark fin soup outside Asia. California's ban on the trade of shark fins was challenged in federal court; it was alleged that the ban violated the Supremacy Clause under Art. VI of the U.S. Constitution and the Commerce Clause under Art. I, s. 8 of the U.S. Constitution. Contrary, the 9th Circuit Court of Appeals held that states are authorized to regulate on-land activities, as the Magnuson-Stevens Fishery Conservation and Management Act was enacted as a federal-state partnership and expressly preserved the jurisdiction of the states over fishery management within their boundaries. In addition, the court held that the ban did not violate the Commerce Clause as it does not interfere with the activity that is inherently national or that requires a uniform system of regulation. Its purpose is to conserve state resources, prevent animal cruelty, and protect wildlife and public health, purposes which are matters of local concern.

\subsection{Shark Finning Legislation in Florida}

The port of Miami is currently the largest port for the landing of shark fins in the United States, "and shark fins from Central America often pass through Miami International Airport on their way to Hong Kong, according to data supplied by the private trade data aggregate Import Genius." ${ }^{\circ 5}$ This happened since Texas and California tightened restrictions on importing and exporting shark fins, so the shark fin business moved to Florida. Before the Texas and California ban restrictions, Los Angeles and Houston were popular transit hubs for Central American fins. The former Florida law had unintentionally allowed the black market of shark finning to flourish by allowing unregulated import/exports that constituted a legal conduit for illegal contraband to mask itself and enter the legal transshipment market.

\section{Florida Administrative Code 68B-44, Sharks \& Rays}

The Code contains relevant information regarding the harvesting of sharks on the coast of Florida within Florida's seaward boundary: The allowed gear, prohibited gear, methods of harvest, and harvesting limitations. "Two or more recreational harvesters aboard a vessel in or on Florida Waters may not collectively possess or land more than two sharks, regardless of the number of persons aboard." ${ }^{\circ 6}$ In addition, certain shark species, including any part of these species, are prohibited under state law from being harvested, possessed, landed, purchased, sold, or exchanged in the state. "The bag, possession, landing, and prohibited species requirements of this rule do not apply to sharks lawfully harvested in federal waters when such sharks are transported directly through Florida Waters with gear appropriately stowed." 67 The commercial harvest season officially extends the entire year but can be closed if any adjacent federal waters are closed.

\section{Florida Fish and Wildlife Commission}

The article IV, § 9 of the Florida Constitution: "The commission (Fish and Wildlife Conservation Commission) shall exercise the regulatory and executive powers of the state for wild animal life and freshwater aquatic life, and shall also exercise regulatory and executive powers of the state concerning marine

65 Shark Allies, What is Happening in Florida, website: https://www.sharkallies.com/ending-the-trade-of-sharkfins/2018/8/25/ending-the-trade-in-florida [Last visited June 1, 2021]

${ }^{66}$ Florida Administrative Code R. 68B-44.004, 1b (2020)

${ }^{67}$ Florida Administrative Code R. 68B-44.004, 4 (2020)

website: www.flrules.org/gateway/ChapterHome.asp?Chapter=68B-44 [Last visited June 1, 2021] 
life. "68 Through Florida Fish and Wildlife Conservation Commission (FWC), the state regulates the harvesting of sharks and the gear used. The FWC has more than 800 sworn law enforcement officers who work to conserve thousands of wildlife species, fresh and saltwater fish. The FWC Division of Law Enforcement is one of the most vital forces for conservation in the nation. These are highly trained, versatile law enforcement officers with full police powers with state and federal jurisdiction.

They are responsible for three million acres of freshwater lakes, 11.000 miles of rivers, streams, and creeks, 8.400 miles of coastline, and nearly 13.000 square miles of ocean. They also provide law enforcement services in the rural, wilderness, and offshore areas where no other law enforcement agencies routinely patrol. As of 2019, new FWC rules were instated regulating land-based shark fishing (started by concerned citizens); requirements include mandatory education course for permit applications, no chumming on the beach, immediate release of prohibited shark species, gear requirements (such as wire cutter) and keeping prohibited species in the water.

\section{Case Study, Kristin Jacobs Ocean Conservation Act}

\section{Introduction to the KJOCA}

The act prohibits the sale of shark fins and the import and export of shark fins to and from Florida. However, the prohibition on sale and export does not apply to commercial fishers who hold a valid federal shark fishing permit on January 1, 2020, or to seafood dealers who harvest and possess sharks, shark fins, and associated shark products that are legally landed, handled, processed, and transported. This exception expires on January 1, 2025.

The origins of "ending the trade" of shark fins: the Florida campaign started with a little-known television phenomenon called Shark Week on Discovery Channel. In the summer (2018), Shark Week celebrated its 30th year on the air and opted for conservation-minded programming given the status of shark populations worldwide. Shark Allies was featured at Shark Week and Shark Tank collaboration. Shark Allies and their executive director, Stefanie Brendl, have also been behind many successful state laws to end the shark fin trade.

On March 12th, 2020, the Florida legislature passed SB680 with unanimous votes in both the Senate and the House. The Kristin Jacobs Ocean Conservation Act (KJOCA) was named The Kristin Jacobs Ocean Conservation Act after the House sponsor Kristin Jacobs. September 19, 2020, Governor Ron De Santis signed a measure into law banning the import and export of shark fins in Florida. Senator Travis Hutson sponsored the bill. Jacobs listed as a priority a ban on the shark fin trade.

Jacobs and other proponents of the bill have condemned the practice of shark finning, where traders cut the fins off a shark but leave the body in the ocean. Without those fins, the shark will almost surely die from blood loss or drowning, as it can no longer swim. ${ }^{69}$

Objective: This legislation intends to stop the flow of fins coming through Florida ports of entry and avoid supporting the global trade of fins. Further, the bill eliminates the incentive for illegal finning.

\subsection{Kristin Jacobs Ocean Conservation Act (Analysis)}

The KJOCA set a case that will serve the shark fin legacy within the U.S. legislation and globally, bring important outcomes on animal protection. The importance of sharks in Florida is not only due to their role in marine environments; they are also the pillar of the economy for many communities, as tourism around sharks has many ramifications.

The primary motivation for creating the KJOCA was the increment of the fin trade through the ports of Miami; this occurred as a consequence of the implementation of bans on the shark fin trade in Texas and California. Since the U.S. is a Federation within the Nation, there are differences among state jurisdictions; this presents other challenges than in unitary systems given these differences is more challenging to regulate, control, and enforce the shark fin bans, particularly in a large country such as the U.S.

Another challenge comes as well regarding shark welfare among states. In some states, sharks have more protection than others, meaning that shark finning is prohibited in some states and others not. It is also

\footnotetext{
${ }^{68}$ Florida Constitution (1998), Article IV, §9,

website: www.leg.state.fl.us/statutes/index.cfm?submenu=3\#A4S09 [Last visited June 1, 2021]

${ }^{69}$ NICOL, R., Gov. DeSantis signs measure banning import and export of shark fins, in Florida Politics (September 19, 2020), website: https://floridapolitics.com/archives/368248-governor-signs-measure-shark-fins/ [Last visited June 1, 2021]

98 Derecho Animal. Forum of Animal Law Studies, vol. 12/3
} 
worth mentioning that the concept of shark welfare or any affirmation regarding the welfare of these animals is not mentioned. Despite the incorporation of one of the best welfare practices such as landing sharks with their fins attached and the ban in the possession, import, export, and sale of separated shark fins, there is no reference made to shark welfare as we have seen in animal welfare legislations such as the Humane Slaughter Act.

Experts agree that the only way to prevent finning is to require sharks to be landed with their fins still naturally attached, but it is nearly impossible to identify fins from different species once they have been detached, meaning that enforcement officials cannot determine from what species these fins come from or whether they were legally acquired.

The obligation to land sharks whole is an improvement to finning laws, but unfortunately, it does not stop the finning problem; the practice of shark finning continues because it is tough to monitor what happens at sea. Once landed, whole sharks are processed quickly and without supervision, making it very difficult to determine whether the rules are being followed: once fins are cut, there is no exact way to know where they came from. Contrary, as others had considered, using every part of the shark does not necessarily make shark fishing sustainable. KJOCA takes a step further by prohibiting the movement of fins coming through Florida ports of entry and avoiding supporting the global trade of fins, consequently eliminating the motivation for illegal finning.

KJOCA did not succumb to the pressure of the fishing industry, making a point of supporting more conservation-oriented businesses. Sharks are seen here as an essential resource to be exploited efficiently and profitably, but ethically. Sometimes people drafting this kind of legislation are related to the fishing industry, which creates biased laws that will tend to protect the commerce instead of the welfare of animals.

This Act highlights shark tourism as an excellent commercial alternative to fishing, preserving sharks while profiting from their presence. It serves as a good strategy for shark conservation and to boost Florida's economy. It is known among the diving community that shark diving also helps by monitoring populations; this can be a way to increase the patrol on waters and protect marine ecosystems.

The U.S. has a strong culture of public engagement and citizen participation. This has ensured that animal welfare aspects do not go overseen as it usually happens in other countries. In the case of KJOCA, citizen participation was crucial as Floridians heard the proposal and voted the former bill KJOCA into Law. The work done by different ONGs such as Shark Allies, the people who demonstrate a great concern about the problem, and the cooperative attitude from the government who showed to be open to the Floridians' demands helped shape this great piece of legislation. It is also important to mention the remarkable support and collaboration of the Animal Law Section of the Florida Bar, which spread this campaign among the legal community in Florida. The success of KJOCA could not have been achieved without the strategic and unified collaboration of all these essential groups; this demonstrates that further steps can be taken to improve this type of Act when implementing similar legislation in other areas within the country. 


\begin{tabular}{|c|c|}
\hline $\begin{array}{l}\text { Kristin Jacobs Ocean Conservation Act } \\
\text { Coding: Words stricken are deletions; words } \\
\text { underlined are additions. }\end{array}$ & Comments \\
\hline $\begin{array}{l}\text { Section } 1 . \\
\text { This act may be cited as the "Kristin Jacobs Ocean } \\
\text { Conservation Act." }\end{array}$ & $\begin{array}{l}\text { Change their Name in honor of Kristin Jacobs, } \\
\text { who passed last summer }\end{array}$ \\
\hline $\begin{array}{l}\text { Section } 2 . \\
\text { Section } 379.2426 \text {, Florida Statutes, is amended: } \\
379.2426 \text { Regulation Possession-of separated } \\
\text { shark fins on the water prehibited; penalties. } \\
\text { (1) As used in this section, the term: } \\
\text { (a) "Land" means the physical act of bringing a } \\
\text { harvested organism, or any part thereof, ashore. } \\
\text { (b) "Shark" means any species of the orders } \\
\text { Carcharhiniformes, } \\
\text { Hexanchiformes, Oamniformes, } \\
\text { Pristiophoriformes, } \\
\text { Squatiniformes, or any part thereof. } \\
\text { (c) "Shark fin" means the detached fin of a shark, } \\
\text { including the caudal or tail fin, or any portion } \\
\text { thereof. } \\
\text { (d) "Separated," with respect to a shark fin, means } \\
\text { not naturally attached to the corresponding shark } \\
\text { body through some portion of uncut skin. }\end{array}$ & See Table below Analysis (HB401, amendment) \\
\hline $\begin{array}{l}\text { (2) A person may not possess in or on the waters } \\
\text { of this state a shark fin that has been separated } \\
\text { from a shark or land a separated shark fin in this } \\
\text { state, unless: } \\
\text { (a) Such possession is authorized by commission } \\
\text { rule; or } \\
\text { (b) Such fin has been lawfully obtained on land, } \\
\text { prepared by taxidermy, and is possessed for the } \\
\text { purposes of display. }\end{array}$ & $\begin{array}{l}\text { (b) The instruction of sharks be landed with their } \\
\text { fins attached is one of the most consistent means } \\
\text { of enforcing a ban on shark finning and also a } \\
\text { better welfare practice, because doing this it could } \\
\text { mean that fisherman would not kill sharks only for } \\
\text { their fins; therefore fewer sharks could be caught } \\
\text { in one trip. Unfortunately, this prohibition has not } \\
\text { been sufficiently effective in stopping the trade of } \\
\text { fins in other countries. }\end{array}$ \\
\hline $\begin{array}{l}\text { (3) Notwithstanding any other law, the import, } \\
\text { export, and sale of shark fins is prohibited and } \\
\text { nothing in this section authorizes such activities. }\end{array}$ & See Table below Analysis (HB401, amendment) \\
\hline $\begin{array}{l}\text { (4) The prohibitions under subsection (3) do not } \\
\text { apply to any of the following: } \\
\text { (a) The sale of shark fins by any commercial } \\
\text { fisherman who harvested sharks from a vessel } \\
\text { holding a valid federal shark fishing permit on } \\
\text { January } 1,2020 \text {. } \\
\text { (b) The export and sale of shark fins by any } \\
\text { wholesale dealer holding a valid federal Atlantic } \\
\text { shark dealer permit on January } 1,2020 \text {. } \\
\text { (c) The export and sale of domestically sourced } \\
\text { shark fins by any shark fin processor that obtains } \\
\text { fins from a wholesale dealer holding a valid } \\
\text { federal Atlantic shark dealer permit on January } 1 \text {, } \\
\text { 2020. }\end{array}$ & $\begin{array}{l}\text { Grants a temporary exemption for licensed } \\
\text { commercial fishers or wholesalers that operate in } \\
\text { Florida, who were holding a valid federal shark } \\
\text { fishing or wholesale permit on January } 1,2020 \text {. } \\
\text { Licenses obtained or transferred after this date will } \\
\text { not be exempt; this does not mean permit holders } \\
\text { are granted forever. }\end{array}$ \\
\hline $\begin{array}{l}\text { (5)(3)-A person who violates this section is subject } \\
\text { to the following penalties: (5) A person who } \\
\text { violates this section is subject to the following } \\
\text { penalties }\end{array}$ & See Table. \\
\hline
\end{tabular}


Section 3.

(1) The Fish and Wildlife Conservation Commission shall evaluate the potential economic impact to the commercial shark fishing industry associated with the prohibition of the import, export, and sale of shark fins in Florida. Based on any identified negative economic impacts to the commercial shark fishing industry, the commission shall identify actions to lessen or offset impacts on the industry to the extent practicable. The commission also shall review the potential impact on shark populations associated with the prohibition of the import, export, and sale of shark fins in Florida. The commission may review and include any other information it believes is relevant to the management of shark fisheries. The commission shall report its findings to the Governor, the President of the Senate, and the Speaker of the House of Representatives by December 31, 2021.

(2) After receipt of the report submitted pursuant to subsection (1), the Legislature may, based upon the findings of the report, impose a ban on the domestic production of shark fins.

Section 4.

This act shall take effect October 1, 2020.

Table (5) A person who violates this section is subject to the following penalties:

\begin{tabular}{|c|c|c|c|c|}
\hline Violations & $\begin{array}{l}\text { Type of Criminal } \\
\text { Infraction }\end{array}$ & $\begin{array}{l}\text { Civil Penalty and } \\
\text { Jail Time }\end{array}$ & $\begin{array}{l}\text { License } \\
\text { Restrictions }\end{array}$ & $\begin{array}{l}\text { Administrative } \\
\text { Fines }\end{array}$ \\
\hline 1st offense & $\begin{array}{l}\text { 2nd Degree } \\
\text { Misdemeanor }\end{array}$ & $\begin{array}{l}\text { Max: } \$ 500 \\
\text { Max: } 60 \text { days }\end{array}$ & $\begin{array}{l}\text { Suspension } \\
\text { license for } 180 \\
\text { days }\end{array}$ & $\$ 4,500$ \\
\hline 2nd offense & $\begin{array}{l}\text { 2nd Degree } \\
\text { Misdemeanor }\end{array}$ & $\begin{array}{l}\text { Max } \$ 500 \\
\text { Max: } 60 \text { days }\end{array}$ & $\begin{array}{l}\text { Suspension } \\
\text { license for } 365 \\
\text { days }\end{array}$ & $\$ 9,500$ \\
\hline $\begin{array}{l}\text { 3rd offense and } \\
\text { subsequent } \\
\text { offenses }\end{array}$ & $\begin{array}{l}\text { 1st Degree } \\
\text { Misdemeanor }\end{array}$ & $\begin{array}{l}\text { Max: } \$ 1,000 \\
\text { Max: } 1 \text { year }\end{array}$ & $\begin{array}{l}\text { Permanent } \\
\text { revocation of all } \\
\text { license privileges }\end{array}$ & $\$ 9,500 "$ \\
\hline
\end{tabular}

Florida Statute $§ 379.2426$ (HB401, amendment) shark fins.

An act relating to shark fins; amending s. 379.2426, 2 F.S.; prohibiting the import, export, and sale of

\begin{tabular}{|l|l|}
\hline CS/HB 401 & Comments \\
$\begin{array}{l}\text { Coding: Words stricken are deletions; words } \\
\text { underlined are additions. }\end{array}$ & $\begin{array}{l}\text { This section creates a violation of state law to } \\
\text { Section 1. Section 379.2426, Florida Statutes, is } \\
\text { amended to read: }\end{array}$ \\
\hline \begin{tabular}{l} 
strengthens state law enforcement's ability to steal \\
\hline
\end{tabular}
\end{tabular}


379.2426 Possession, import, export, and sale of separated shark fins on the water prohibited; penalties.

(1) As used in this section, the term:

(a) "Land" means the physical act of bringing a harvested organism, or any part thereof, ashore.

(b) "Shark" means any species of the orders Carcharhiniformes,

Hexanchiformes,

Pristiophoriformes, Lamniformes, Orectolobiformes, Squaliformes, Squatiniformes, or any part thereof.

(c) "Shark fin" means the detached fin of a shark, including the caudal or tail fin, or any portion thereof.

(d) "Separated," with respect to a shark fin, means not naturally attached to the corresponding shark body through some portion of uncut skin.

(2) A person may not possess in or on the waters of this state a shark fin that has been separated from a shark or land a separated shark fin in this state, unless:

(a) Such possession is authorized by commission rule; or

(b) Such fin has been lawfully obtained on land, prepared by taxidermy, and is possessed for the purposes of display. action against those harvesting and exporting fins. In addition, it closes Florida's sea, and airports as a conduit for fins from other states and foreign countries to enter the global market and mandates state law enforcement agencies to increase their efforts, in performance with Federal agencies, to inspect, intercept and seize fin shipments.
The bill expands enforcement of shark fin laws on land. However, nothing has been changed within the statute to prohibit the possession of shark fins on land.

Nevertheless, this is a step forward to control the shark finning practice, although it makes it very difficult to enforce, given that this regulation can only take place when someone is caught finning a shark in open water.

Before the fins were separated from the shark's body, it was almost impossible to recognize if a law was broken unless the fin was evidently from a protected or endangered species.

(3) Notwithstanding any other law, the import, export, and sale of shark fins is prohibited and nothing in this section authorizes such activities.

(4)(3)-A person who violates this section is subject to the following penalties:

(5) The prohibition of the export and sale of shark fins under subsection (3) does not apply to commercial fishermen who hold a valid federal shark fishing permit on January 1,2020, or to seafood dealers who harvest and possess sharks, shark fins, and associated shark products that are legally landed, handled, processed, and transported. This subsection expires on January 1, 2025.

Section 2.

This act shall take effect October 1, 2020.

\section{Importance of Stronger legislation for Sharks}

\subsection{Awareness of the Cruelty of Shark Finning}

In his 1840 book The Basis of Morality, Arthur Schopenhauer states that "the assumption that animals are without rights and the illusion that our treatment of them has no moral significance is a positively outrageous example of Western crudity and barbarity. Universal compassion is the only guarantee of morality." Therefore, it is essential to advance on moral arguments for conservation and animal welfare based not only on human interests but also on an ecocentric standard. From what we have previously seen on the KJOCA, we can conclude that people care about animals, the welfare of sharks has become a big concern 
among people. Therefore, more actions should be taken to consider the public opinion on these matters; in the end, people will be the ones to decide if they would buy a shark soup bowl that has come from the suffering and misery of a shark or buy something else instead.

We cannot continue seeing the world and its inhabitants as only ours; we need to implement a more ethical, scientific, sustainable, and ecocentric perspective on how we relate to nature, especially animals, particularly sharks. Many people have expressed a genuine concern and opposition to shark finning, which the majority consider a brutal practice.

Culture and traditions strongly influence the way humans treat animals and sometimes override morals and judgment. Fortunately, the fast dissemination of information through the internet is helping to debunk some outdated beliefs and create opposition against immoral traditions, thus shaping our culture. For example, a decade ago, most Chinese citizens did not know the process of shark fin soup. However, after much publicity about the matter, especially from the famous Chinese star basketball player Yao Ming, who partnered with the anti-wildlife trade organization Wild Aid in 2011, more people became aware of shark fin soup and the irreversible damage was done to the marine ecosystem.

By 2013 the public perception and acceptance of "fish-fin soup" had drastically changed. The former NBA (National Basketball Associations) star has truly helped curb China's consumption of shark fin soup by becoming the face of a campaign of commercials and documentaries exposing how the "delicacy" has made many shark species endangered. ${ }^{70}$

The change in the perception of shark fin soup might have brought a new generation of change in this matter. In 2013, China banned shark fin soup from all government banquets. Although the shark fin soup banned did not stem from the concern from these animals but from the desire to reduce costs of official events, the decision might have been influenced by public morality. Consequently, several private companies are also declining to ship or sell shark fin products, however, as companies and states close the door on shark fin trade, other doors remain open, and the market moves consequently.

Older cultures that maintain a closer relationship with nature, such as the Maori, offer other perspectives on shark finning. For example, the extinction of these species could be considered a threat to the Maori heritage. Therefore, their voice in the New Zeeland Government could make a difference when creating laws to protect sharks; this is another case highlighting the importance of citizen participation and showing how public engagement can play an essential role in protecting sharks and other threatened animals.

There is a more prevalent social concern about the well-being of sharks worldwide, but it has not been strong enough to call finning a threat to public morality. The argument used to convince the World Trade Organization to implement the 2009 ban on the trade of seal products in the E.U. could also protect sharks. However, no matter how cruel the practice of finning is, sharks are viewed by the public as dangerous animals, primarily due to the fictional depiction of sharks in movies. It is easier to raise a case of public morality when someone is trying to defend a cute baby seal instead of a ravenous monster.

\subsection{Shark Welfare and Exclusions of Legal Protection}

Despite enough evidence to conclude that sharks are sentient animals, no effort to recognize them has been made. Conservation \& Trade Laws focus on preserve shark populations for stock rather than the individuals and their welfare necessities. Welfare is not a priority or even a concern for the international institutions in charge of preserving, protecting, and regulating the trade of sharks. Some key aspects must be addressed in the existing regulations to deliver more efficient and robust legislation to protect sharks.

International treaties that attempt to protect sharks have a crippling weakness: they are not legally binding. IPOA-Sharks was the first multilateral organization that tackled shark finning, highlighting the importance of using sharks entirely and not only their fins. Unfortunately, IPOA-Sharks can only emit recommendations, and these cannot be enforced, leaving sharks to the mercy of the parties.

Countries tend to stay idle to protect sharks without monetary support, cooperation with other countries, research, and data exchange. The CMS provides tools that help improving shark protection at the international level, and these elements are the key to its success. Unfortunately, the CMS merely lists three of the 197 shark species that IUCN or TRAFFIC (Trade Records Analysis of Flora and Fauna in Commerce) consider endangered on either Appendix I or Appendix II.

The IUCN plays a decisive role in protecting sharks since it provides conservationists and lawmakers with the necessary scientific data to make informed decisions. With this information, conservationists can

${ }^{70}$ STEFFEN, A., Slaughter of sharks for their fins goes down $80 \%$ and basketball star Yao Ming is a major influence (2019), website: https://www.intelligentliving.co/shark-yao-ming/ [Last visited May 19, 2021] 
convince Lawmakers to create rules and regulations that protect sharks reflecting the critical situation they live in.

CITES offers specific protection through trade regulations, but their regulations do not reflect the current problem since they update their lists every five years. Regarding welfare, CITES only covers some elements related to the facilities used to house animals and some provisions about their transport; but this does not encompass any aspects of shark's welfare.

The OIE, on the other hand, does concern itself with animal welfare, mainly in order to offer food safety to humans. However, the regulations issued within the OIE Aquatic Animal Health Code provide standards for the welfare of farmed fish, but it does not extend to wild fish, leaving sharks out.

Sharks are excluded from the most critical Animal Welfare legislation in the U.S., such as the Animal Welfare Act, Federal Meat Inspection Act, and the Lacey Act. Even though the Endangered Species Act includes sharks, it has proven insufficient in protecting them because only two species are included.

Sharks are commonly overlooked and poorly understood; they require more from us in legal protection. There has been no entity dedicated to analyzing the issues related to the welfare of sharks, neither a scientific and economic analysis resulting from the use of these animals. Scientists less study shark capabilities and are even considered abnormal creatures that cannot feel pain.

Speciesism is present in the current animal welfare legislation by contrasting the marine animals and terrestrial animals and aquatic animals such as mammals and non-mammals, such as the Marine Mammal Protection Act, where sharks by definition are omitted. In one of the most critical legislations in animal welfare in the country, such as the Animal Welfare Act, sharks are also excluded from protection since they are invertebrate. Unfortunately, this tends to be a common problem in the world of animal protection, but the Law should not distinguish between animals, especially when making decisions that affect their lives and welfare. It should be relevant to consider the critical role of these animals within ecosystems and their individual capacities and biological needs. It is essential to contemplate the questions raised by the finning and all that it implies.

We should consider an ethical and more scientific approach when treating these animals. Demanding welfare for sharks does not imply that we should stop profiting from these animals; it means that when we do it, we should treat them as humanely as possible in order to improve their welfare while they are under our care, even if it is just on the last moments of their lives.

\subsection{Strengths and Weaknesses of the Shark Finning Legislation}

The International and domestic legislation about shark finning present several weaknesses and loopholes, such as the lack of regulation and enforcement given the habitat of these animals; it is very challenging to monitor what happens at sea. Only with a ban on the trade could we bring an end to this practice, even though that does not mean that we would end with it the suffering of sharks. There are other threats to them, such as bycatch and water pollution, pushing them to the brink of extinction.

The first challenge in any federated system such as the U.S. is achieving interstate cooperation. Unfortunately, the lack of standardization among shark finning legislation in different states makes regulation and enforcement problematic; this is why the current shark finning legislation could be divided into three levels of protection: none, low, medium, and high.

The weakest type of shark finning legislation is the one that offers no kind of shark fin ban. In the U.S., only 14 states have a shark finning ban. Followed by the regulations which require fishers to show fin to carcasses ratio, offering them low protection, as it is not very effective, such as the case of (states) At the federal level, the Shark Finning Prohibition Act of 2000 does not require carcasses be brought ashore with fins attached, relying instead on a fin-to-carcass ratio creating a loophole in the regulation which decimate its effectiveness.

Some states have achieved significant results in fighting the shark finning issue by implementing rules requiring whole sharks to be landed, which is more efficient than other bans, which only require fishers to show the right proportion of fins and shark carcasses. While this may be considered unimportant, we should consider that a shark's liver is extremely heavy concerning its body weight, so once the shark carcasses are on the boats, fishers can quickly reduce excessive weight by removing the shark guts the animal. Furthermore, the "fins naturally attached" policy is a more effective way of protecting sharks from being overexploited by the practice of finning. Finally, the best policy for shark protection could be implementing bans on the trade of shark fins; this would not leave loopholes for opportunistic fishers to take advantage of these types of bans.

Fin trade bans and finning bans present a significant weakness due to the difficulty of enforcement. The Magnuson-Stevens Fishery Conservation and Management Act urges to follow a more conservationist fishing method, given the notable decline in fish stocks, including sharks. The main objective is to preserve animal 
species used for fishing, their habitats and combat overfishing. The Shark Fin Sales Elimination Act of 2019 was proposed as an effective tool to finally end the shark finning practice because it makes it illegal to possess, buy, or sell shark fins or any product containing shark, except for particular dogfish fins. A person may possess a shark fin that was lawfully taken consistent with a license or permit under certain circumstances. Even though shark finning is banned in the U.S., the trade of shark fins is still allowed in the country. The Shark Fin Sales Elimination Act would end the United States' role in perpetuating the finning industry by banning the sale, possession, or purchase of shark fins as well as its byproducts.

Some advances in the legal protection of sharks have been shown by creating Marine Protected Areas and Moratoriums and requiring fishers to land sharks with the fins naturally attached, which translates into high protection. In addition, the Shark Conservation Act of 2010 requires fishers in U.S. waters to bring sharks ashore with fins naturally attached. Unfortunately, this can only be enforced before the sharks are fully processed, which happens quicker than we can imagine once the shark's body arrives on land. Furthermore, there is no precise way to know where they originally came from once fins are cut. Even more complicated when fins are found frozen in a warehouse, how could we know if sharks were finned at land or come from illegal practices at sea?

To make things worse, the SCA prohibits anyone under U.S. jurisdiction from engaging in finning, but many consumers have primarily turned to international markets for fin imports. The inconsistencies in the data related to importing and exporting shark fins from and to the United States are worrying; this shows how the current bans are not very effective

According to the Food and Agriculture Organization of the United Nations (FAO), other countries reported exporting 1,012 metric tons of shark fins to the United States in 2007. However, that same year, the National Oceanic and Atmospheric Administration (NOAA) reported 28.8 metric tons of shark fin

imports.

In 2011, NOAA reported 38 metric tons of shark fin exports from the United States, yet according to the FAO, other countries reported importing 295 metric tons of shark fins from the United States. ${ }^{71}$

Other problems affect sharks in U.S. waters; for example, the Fish and Wildlife Conservation Commission (FWC) does not track which species are caught for their fins. According to the FWC, large coastal sharks are primarily protected in State waters, yet a commercial vessel can catch up to 45 per day in Federal waters. Small coastal sharks do not even have a limit unless the FWC puts in place a seasonal quota. Pelagic, or open water sharks, have even less protection than that. According to permit limits, based on NOAA's stock assessment 2020 of commercial Atlantic shark fishing quotas, they start the year with no additional quotas, other than 45 per vessel per day. This number, again, is just for large coastal sharks. Under NOAA, small coastal sharks are often called "non-black noses," and most pelagic species have no catch limits.

Dozens of shark species are veiled by the designation of "non-black nose," "non-sandbar," "large coastal sharks," "small coastal sharks," and "pelagic sharks."72

Millions of pounds of spiny and smooth dogfish sharks are caught by fishermen every year, and only recently have managers begun to implement science-based quotas and consider the importance of reducing bycatch or the incidental taken of species. Although smooth dogfish have never been formally assessed to determine how big the population is, fishers can catch an unlimited, unregulated amount. As a result, dogfish (smaller shark species) are excluded from protection. While both smooth and spiny dogfish are smaller shark species, therefore, less vulnerable to fishing pressure, they are still sharks and need the same protection.

There is also considerable confusion when labeling rules and commodity codes. For example, the United States requires shark fins to be labeled as shark fins only if they are dried. If shark fins are wet, fresh, frozen, or processed in another way other than being dried, the sellers are not forced to label them as shark fins. This limited and not well-standardized requirement adds further challenges to the collection of import/export data. Under current regulations, it is tough to know if a fin came initially from a managed fishery or not under current regulations. In the end, it little matters if these fins were taken legally or illegally, through finning in water or after being processed on land, the outcome is the same. Millions of sharks are taken to supply the trade of fins.

At the state level, there are few examples of high legal protection for sharks. In Texas, for example,

\footnotetext{
${ }^{71}$ Shark Allies, Import and Export Issue, website: www.sharkallies.com/ending-the-trade-of-shark-fins/import-and-export-issue [Last visited May 31, 2021]

${ }^{72}$ Shark Allies, Current Fishing Regulations, website: www.sharkallies.com/ending-the-trade-of-shark-fins/is-the-global-decline-ofshark-populations-also-happening-in-florida [Last visited May 31, 2021]
} 
Governor Abbott signs in 2016 H.B. 1579 into law, prohibiting the sale, trade, purchase, and transportation of shark fin. Texas also makes great efforts in enforcement and involves the Texan community on the issue and working with their commercial fishing partners to report any illegal activity. The California legislature passed a bill prohibiting the possession, sale, trade, or distribution of shark fins, coming into effect as a law on January 1st, 2012; the purpose of this law is to "conserve state resources, prevent animal cruelty, and protect wildlife and public health," which are matters of local concern. In 2020 Florida took a stand against finning employing the Kristin Jacobs Ocean Conservation Act.

Even though some states have passed laws to ban the trade of shark fins, the finning business seems to thrive because when these products are banned in one State, the market shifts to a new location.

It is also worth mentioning that the standardization of the bans could lead to more efficient enforcement, control, and therefore more comprehensive protection for sharks, this with the strategic collaboration on intersectorial levels, public consultation, funded research, and a more ecocentric perspective, significant progress can be achieved.

\subsection{KJOCA and Shark Protection}

Regardless of the current legislation intended to protect sharks, the number of shark deaths are increasing year by year, and many types of sharks are exploited for their fins, including endangered species such as the Scalloped Hammerhead and Great Hammerhead; this leads to the assumption that there is not enough regulation, enforcement or control to protect these animals. Additionally, the planet is heading to its six ${ }^{\text {th }}$ most catastrophic extinction; climate change is an issue reflected in our everyday life and, most importantly, our health and economies.

The shark-diving industry will collapse if shark populations continue to drop without sharks to observe many businesses worldwide, making money providing shark dives and underwater tours close. Small communities will be seriously affected as shark tours have become their primary source of revenue. A reef shark can generate $\$ 250,000$ through tourism in its life, but a shark caught by a fisherman only produces $\$ 50$.

The ocean will always be a central hub of economic activity. Although the sea provides commercial, recreational, and subsistence fisheries that bring many millions of dollars each year to coastal communities, it also provides a shoreline for boating, sightseeing, vacationing, and other recreational activities, like marine diving. In Florida, deep-sea diving generates a substantial economic impact in most coastal counties. The shark species that are most commonly targeted for their fins are the same species that are the biggest attractions for the dive industry (hammerhead, tiger, bull, lemon, and so on).

Divers spend over a 682million dollars annually to dive reefs, wrecks, and other diving attractions throughout the state's coastal waters. Nearly $20 \%$ of this impact, or $\$ 126$ million, involves targeted shark-related diving. When value-added impacts (multipliers) are included, the total economic impact of targeted shark-related diving is $\$ 217$ million. When considering all divers wishing to have a shark encounter while diving, direct expenditures by these divers reach an estimated $\$ 221$ million annually and $\$ 378$ million when value-added impacts are included. These expenditure impacts translate into $\$ 116$ million in income impacts and nearly 3,800 full-time jobs." ${ }^{, 73}$

Why not then, instead of relying on the shark finning business, which offers a short-term profit, start promoting sustainable ecotourism as a better and profitable business. In this way, live sharks can translate into a significant asset to make a profitable and ethical business.

The KJOAC will set a case for ending the shark finning legacy. The naturally attached fins policy is a positive step in the right direction to protect sharks from the cruelest practice that exists against them, therefore indirectly improves their welfare. In this Act, the importance of sharks to Florida's economy is highlighted. When a shark is sold for meat or fins, it is truly a waste of resources; a live shark has much more value for conservation and the economy. Shark diving is a sustainable and more ethical way of generating income for many sectors of the economy while protecting marine environments and can bring enormous revenue. In addition, live sharks can sustain a market that provides jobs for many people.

\section{Critics and applause to the KJOCA}

They have learned from the fails of "fin to carcasses ratio" regulations; more legislation is being created to apply the "naturally attached fins" policy. Some U.S. states tend to go a step further and stop the trade and

\footnotetext{
${ }^{73}$ FEDLER, A. - Oceana, The Economic Impact of Shark Diving in Florida (USA 2017) 11, website: https://usa.oceana.org/sites/default/files/economic_impact_of_shark_diving_in_florida_report.pdf [Last visited June 1, 2021] 
sale of fins, such as the KJOCA. This Act shows that the importance of live sharks in the waters of Florida is not only reduced to the role they play in the marine ecosystem, but they are vital to the economy. Shark diving is a sustainable and ethical way of generating income for many sectors of the economy while protecting marine environments and bringing enormous revenue. Fighting shark finning through the KJOCA Florida is achieving several goals: it addresses conservation issues and is fighting illegal activities derived from shark fin trade but, above all, is protecting the future of sharks as a source of local income derived from eco-tourism.

The KJOCA also has weaknesses; for instance, it does not include a domestic ban on fin sales on land, which would probably be easier to enforce. The dark nature of the finning industry requires comprehensive legislation that covers all loopholes and discourages all trade. The KJOCA is the latest U.S. legislation on sharks, but it does not mention their welfare.

\section{Conclusion}

Shark finning is not only a cruel practice; it is also an unsustainable and inefficient business. Although sharks play a crucial role in maintaining the equilibrium in our marine ecosystems and are also a great asset to the economy, millions of these animals continue to disappear by this practice, which is unethical but wasteful.

Sharks are often left out of welfare considerations; there are no distinct guidelines for their welfare, which can easily lead not only to the perpetuation of the practice of finning but also to any act of cruelty against them. Furthermore, even though there is scientific evidence demonstrating that fish might feel pain, the fishing industry in some countries categorizes sharks as abnormal creatures with no ability to feel. Even if science cannot assure that sharks can feel pain, the precautionary principle should be applied to offer more comprehensive protection.

Animal Welfare Laws such as the Animal Welfare Act, Marine Mammal Protection Act, and Humane Slaughter Act protect the welfare of vertebrate animals offhand but blatantly exclude sharks from their protection. Likewise, the anthropocentric envision of the Conservation and Trade Laws is opposed to the welfare of sharks. Even the most recent shark finning legislation and binding international agreements such as CITES and international organizations such as the OIE entirely disregard the welfare of shark individuals because their regulations are intended merely to preserve a viable shark stock.

The particular nature of any federated system such as the U.S. regarding their current shark finning legislation presents several difficulties given its heterogeneous characteristics in which every State has its specific bans: enforceability becomes then a real challenge. The distinct management of shark finning practices at the state level also represents difficulties controlling the sale and possession of shark fins. There is a remarkable difference between shark finning prohibitions: from a complete ban including the sale and possession of fins to a ratio-fin carcass tolerance. This last one has proven to be inefficient as it creates a nest for illegal business, corruption and increases the extent of cruelty to which sharks are continuously submitted.

The need for a robust regulation that tackles the shark fin industry cannot be but overemphasized. It is necessary to create coherent solid, homogeneous legislation at a state and international level, urging fishers to bring sharks into port with their fins connected. International treaties should consider the creation of environmental and welfare assessment plans for sharks and the implementation of sanctions or a punishment system for parties failing to adhere to international laws. Each country would have to exercise the enforcing power into their domestic legislation, but every country also would need to have an incentive to comply with international laws with the help of regional or bilateral agreements. This could allow nations to use their market relationship to apply direct pressure on one another to comply. It will also be necessary to strengthen the international programs, including more comprehensive habitat management under an ecocentric approach that does not set aside the individual protection of sharks.

It is vital to incorporate new scientific findings into regulatory decision-making to create efficient legislation; this should lead to developing a shark welfare concept. It would also be essential to conduct extended assessments on shark populations because this could offer a wide spectrum of shark species regarding their reproductive cycles, nursery areas, shark movements, and migration. Studies concerning the economic importance of alternative practices regarding sharks, highlighting their economic value to the local communities, represent a great asset to the legislative process and lobbying, as it was for the Kristin Jacobs Ocean Conservation Act. Imposing a regulation has consequences on the people and should always imply a previous public consultation by generating agreements with the producers (fishers).

A more vital, homogeneous, and coherent legislation inside nations and outside nations internationally could be achieved with the creation of a Strategic Global Plan to protect Sharks \& their Welfare, where shark conservation and welfare converge and not diverge, where collaboration and cooperation take place among government, industry, and citizens. The creation of this Strategic Global Plan should be carried out by an 
inter-sectorial team whose functions should be distributed on a multilevel policy, boosting the understanding among the three levels of government, national and international institutions, and society. They will create a framework of coordination, transversality, and synergy in public policies and the regulatory framework that considers shark conservation and welfare.

One of the goals of this plan would be implementing a dedicated research and monitoring system since what cannot be measure cannot be controlled. Another necessary occurrence is a general increase in funding for research and enforcement. This concept parallels enforcement and monitoring. Monitoring and enforcement cannot occur without more funding. The dialogue between Science and Law cannot be stressed enough. The development of a concept of shark welfare has to be included in the legislation. Economic aspects should also be included to propose alternative, sustainable businesses considering shark conservation and welfare aspects.

Many countries do not realize the immense amount of ecological wealth that exists within their borders; they should consolidate sustainable, productive activities that promote the conservation of animal species such as sharks and contribute to the reduction of poverty and marginalization in the areas where they are distributed, promoting activities such as eco-tourism. Furthermore, all countries should promote education, communication, and awareness about the importance of conservation and welfare of sharks to both developing and developed countries and promote the involvement of communities in conservation actions for sharks while strengthening their technical and management capacities.

The KJOCA offers us an excellent opportunity to learn how people have the power to generate change when they make themselves heard. The people of Florida expressed their social concern about the wellbeing of sharks; this example can be extended to other states or even other nations, given that animal welfare proves to be a growing concern. Many people are unaware of the substantial and irreparable harm they are causing to their ecosystems and these beautiful creatures. Education and information are vital to accomplishing more humane legislation with a solid global unity.

\section{Bibliography \\ Primary Sources}

- Animal Welfare Regulations of 1966, 9 Code of Federal Regulations $\S 1.1$ www.aphis.usda.gov/animal_welfare/downloads/bluebook-ac-awa.pdf

- Department of Commerce - NOAA - NMFS, US National Plan of Action for the Conservation and Management of Sharks (2001) www.fao.org/3/br377e/br377e.pdf

- Endangered Species Act of 1973, 16 U.S.C., Conservation, §1531 (b)

- https://uscode.house.gov/view.xhtml?path=/prelim@title16/chapter35\&edition=prelim

- Federal Meat Inspection Act of 1906, 21 United States Code Annotated (USCA), §601

- www.govinfo.gov/content/pkg/USCODE-2014-title21/html/USCODE-2014-title21-chap12subchapI-sec601.htm

- Federal Meat Inspection Act of 1906, 21 USCA, §603

- www.govinfo.gov/content/pkg/USCODE-2014-title21/html/USCODE-2014-title21-chap12subchapI-sec603.htm

- Florida Administrative Code R. 68B-44.002 (2020)

- www.flrules.org/gateway/RuleNo.asp?ID=68B-44.002

- Florida Administrative Code R. 68B-44.004, 1b \& 4 (2020)

- www.flrules.org/gateway/ChapterHome.asp?Chapter=68B-44

- Florida Constitution (1998), Article IV, §9,

- www.leg.state.fl.us/statutes/index.cfm?submenu=3\#A4S09

- Food and Drug Administration, Fish and Fishery Products of 2020, 21 CFR, § 123.3

- www.accessdata.fda.gov/scripts/cdrh/cfdocs/cfcfr/CFRSearch.cfm?fr=123.3

- Food and Drug Administration, Fish and Fishery Products of 2020, 21 CFR, § 123.5

- www.accessdata.fda.gov/scripts/cdrh/cfdocs/cfcfr/CFRSearch.cfm?fr=123.3

- Magnuson-Stevens Fishery Conservation and Management Act (1976), 16 USC, §1801, sec.2(a)

- www.govinfo.gov/content/pkg/COMPS-1678/pdf/COMPS-1678.pdf

- Marine Mammal Protection Act of 1972, 16 USC 1361-1407, § 1362

- www.fws.gov/international/pdf/legislation-marine-mammal-protection-act.pdf

- Resource Management Act 1991, Section 2, New Zeeland

- www.legislation.govt.nz/act/public/1991/0069/latest/DLM230272.html

- Shark and Fishery Conservation Act (2009), Pub. L. No. 111-348, §103, 124 STAT. 3670, 
- www.congress.gov/111/plaws/publ348/PLAW-111publ348.pdf

- Shark Fin Sales Elimination Act of 2019, H.R.737, §2, 3 \& 4

- www.congress.gov/116/bills/hr737/BILLS-116hr737rfs.pdf

- The Florida Senate, Bill CS/CS/CS/SB 680, Bill Analysis and fiscal impact statement

- https://www.flsenate.gov/Session/Bill/2020/680/Analyses/2020s00680.rc.PDF

\section{Secondary Sources}

- Animal Welfare Institute, Shark Finning,

- https://awionline.org/content/shark-finning

- ARRIBAS, M., Protection of Animals in the Convention on International Trade in Endangered Species of Wild Fauna and Flora (CITES) (Andalucía 2016)

- https://dspace.unia.es/handle/10334/3493

- BENTHAM, J., Introduction to the Principles of Morals and Legislation (London 1823)

- BRENDEL, S. - Snyder, J., Fin-tastic Beasts [Webinar], Animal Law Section of the Florida Bar (2020)

- CATARCI, C., World Markets and Industry of Selected Commercially-Exploited Aquatic Species with an International Conservation Profile (Rome 2004)

- www.fao.org/3/y5261e/y5261e08.htm

- COMPAGNO, L. - DANDO, M. FOWLER, S., Sharks of the World (London 2005)

- Convention of Migratory Species, Introduction

- www.cms.int/en/page/introduction-0

- DAVIS, M. - DUNN, J. - RAYMOND, F. - MYLNICZENKO, N. - STORMS, T., Pain Control in Elasmobranchs? Evaluation of Butorphanol and Ketoprofen as Analgesics in Chain Dogfish (Scyliorhinus retifer), (Dallas 2005)

- www.vin.com/apputil/content/defaultadv1 aspx?pId=11257\&catId=32333\&id=3865178\&ind=2 76\&objTypeID $=17$

- DELL'APA, A. - CHAD SMITH, M. - KANESHIRO-PINEIRO, M.Y., The Influence of Culture on the International Management of Shark Finning, in Environmental Management (2014),

- https://doi.org/10.1007/s00267-014-0291-1

- FEDLER, A. - Oceana, The Economic Impact of Shark Diving in Florida (USA 2017) 11

- Food and Agriculture Organization, International Plan of Action for Conservation and Management of Sharks

- Food and Agriculture Organization, International Plan of Action for Conservation and Management of Sharks

- www.fao.org/ipoa-sharks/en/

- HUETER, R. - TYMINSKI, J., Species-Specific Distribution and Habitat Characteristics of Shark Nurseries in Gulf of Mexico Waters off Peninsular Florida and Texas Center for Shark Research (USA 2007)193

- International Union for the Conservation of Nature, About

- www.iucn.org/about

- IUCN Shark Specialist Group, What We Do,

- www.iucnssg.org/what-we-do.html

- KAWHARU, M., Kaitiakitanga: a Maori anthropological perspective of the Maori socioenvironmental ethic of resource management, The Journal of the Polynesian Society (2000), vol. 109 , no. 4, pp. 349-370,

- www.jstor.org/stable/20706951

- KELEDJIAN, A., Spiny Dogfish Catch a Break-No More Shark Finning in the U.S.!, Oceana [Blog]

- https://oceana.org/blog/2014/11/spiny-dogfish-catch-a-break-no-more-shark-finning-in-the-us

- LANGLEY, L., The Surprisingly Humanlike Ways Animals Feel Pain

- www.nationalgeographic.com/animals/article/animals-science-medical-pain

- MANTECA, X. - MAINAU, E. - TEMPLE, D., What is animal welfare?

- www.fawec.org/en/fact-sheets/28-general-welfare/106-what-is-animal-welfare

- MARSHALL, L. - BARONE, M., Shark Fin Guide: identifying sharks from their fins (Rome 2016) 
- www.fao.org/3/i5445e/i5445e.pdf

- National Oceanic and Atmospheric Administration, Species directory, Scallop Hammerhead shark

- www.fisheries.noaa.gov/species/scalloped-hammerhead-shark

- NICOL, R., Gov. DeSantis signs measure banning import and export of shark fins, in Florida Politics (September 19, 2020)

- https://floridapolitics.com/archives/368248-governor-signs-measure-shark-fins/

- Oceana, The Importance of Sharks,

- https://europe.oceana.org/en/importance-sharks-0

- ROGERS, M., Why All Shark Species Are Important,

- www.sharksider.com/shark-species-important/

- Sea Shepherd UK, Sharks, Drugs, Lies, and Corruption in Costa Rica

- www.seashepherd.org.uk/news-and-commentary/commentary/sharks-drugs-lies-and-corruptionin-costa-rica.html

- Shark Allies, Current Fishing Regulations

- www.sharkallies.com/ending-the-trade-of-shark-fins/is-the-global-decline-of-sharkpopulations-also-happening-in-florida

- Shark Allies, Import and Export Issue

- www.sharkallies.com/ending-the-trade-of-shark-fins/import-and-export-issue

- Shark Allies, What is Happening in Florida

- https://www.sharkallies.com/ending-the-trade-of-shark-fins/2018/8/25/ending-the-trade-inflorida

- SHARPLESS A., The Value of Keeping Sharks Alive, Oceana (2017) [Blog]

- https://oceana.org/blog/value-keeping-sharks-alive

- SNEDDON, L., Pain in aquatic animals. The Journal of experimental biology (2015), 218(7) 969.

- https://www.wellbeingintlstudiesrepository.org/cgi/viewcontent.cgi?article=1054\&context=acw p_asie

- STEFFEN, A., Slaughter of sharks for their fins goes down $80 \%$ and basketball star Yao Ming is a major influence (2019)

- https://www.intelligentliving.co/shark-yao-ming/

- TE AHUKARAMŪ, C.R., Tangaroa - the sea - The importance of the sea, Te Ara - the Encyclopedia of New Zealand,

- www.TeAra.govt.nz/en/tangaroa-the-sea/page-1

- TRAN B., Eating Our Way to Their Extinction: What Florida Should Learn From California on Banning Shark Fin Soup and the Shark Fin Trade (Seattle 2019)

- https://digitalcommons.law.seattleu.edu/cgi/viewcontent.cgi?article=1079\&context=sjel

- VANNUCCINI, S., Shark Utilization, Marketing and Trade (Rome 1999)

- www.fao.org/3/x3690e/x3690e00.htm\#Contents

- WISCH, R., Michigan State University College of Law (2003),

- www.animallaw.info/article/overview-lacey-act-16-usc-ss-3371-3378

- World Organization of Animal Health (OIE), Introduction to the recommendations for animal welfare,

- www.oie.int/fileadmin/Home/eng/Health_standards/tahc/2018/en_chapitre_aw_introduction.ht $\mathrm{m}$

\section{Other sources}

- Convention of Migratory Species, Introduction: https://www.cms.int/en/legalinstrument/cm 